\title{
Bone volume changes after immediate implant placement with or without flap elevation.
}

\section{Fabio Mazzocco}

ADVERTIMENT. La consulta d'aquesta tesi queda condicionada a l'acceptació de les següents condicions d'ús: La difusió d'aquesta tesi per mitjà del servei TDX (www.tesisenxarxa.net) ha estat autoritzada pels titulars dels drets de propietat intel-lectual únicament per a usos privats emmarcats en activitats d'investigació i docència. No s'autoritza la seva reproducció amb finalitats de lucre ni la seva difusió i posada a disposició des d'un Iloc aliè al servei TDX. No s'autoritza la presentació del seu contingut en una finestra o marc aliè a TDX (framing). Aquesta reserva de drets afecta tant al resum de presentació de la tesi com als seus continguts. En la utilització o cita de parts de la tesi és obligat indicar el nom de la persona autora.

ADVERTENCIA. La consulta de esta tesis queda condicionada a la aceptación de las siguientes condiciones de uso: La difusión de esta tesis por medio del servicio TDR (www.tesisenred.net) ha sido autorizada por los titulares de los derechos de propiedad intelectual únicamente para usos privados enmarcados en actividades de investigación y docencia. No se autoriza su reproducción con finalidades de lucro ni su difusión y puesta a disposición desde un sitio ajeno al servicio TDR. No se autoriza la presentación de su contenido en una ventana o marco ajeno a TDR (framing). Esta reserva de derechos afecta tanto al resumen de presentación de la tesis como a sus contenidos. En la utilización o cita de partes de la tesis es obligado indicar el nombre de la persona autora.

WARNING. On having consulted this thesis you're accepting the following use conditions: Spreading this thesis by the TDX (www.tesisenxarxa.net) service has been authorized by the titular of the intellectual property rights only for private uses placed in investigation and teaching activities. Reproduction with lucrative aims is not authorized neither its spreading and availability from a site foreign to the TDX service. Introducing its content in a window or frame foreign to the TDX service is not authorized (framing). This rights affect to the presentation summary of the thesis as well as to its contents. In the using or citation of parts of the thesis it's obliged to indicate the name of the author. 


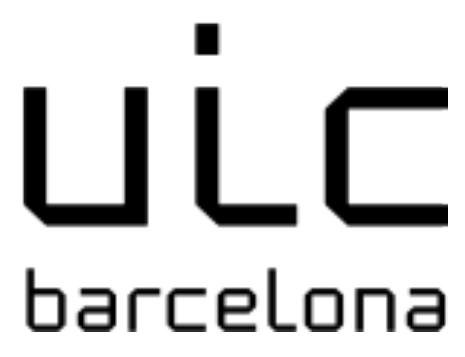

Bone volume changes after immediate implant placement with or without flap elevation.

Fabio Mazzocco

April, 2016 


\section{Bone volume changes after immediate implant placement with or without flap elevation.}

\section{Fabio Mazzocco}

Department of Periodontology, Universitat Internacional de Catalunya

Department of Periodontology, University of Padova

Director: Dr. Jose Nart 
AKNOWLEDGEMENTS 
AKNOWLEDGEMENTS

To my wife and my family for their unconditional support 
TABLE OF CONTENTS 


\section{TABLE OF CONTENTS}

- SUMMARY ..................................................................... 8

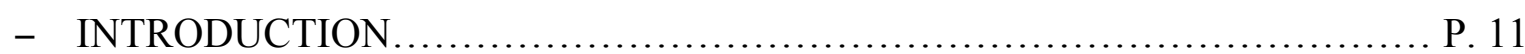

- BACKGROUND................................................................ 14

Dimensional changes of the alveolar ridge after tooth extraction

Timing of implant placement

Immediate implant placement

Hard and soft tissue changes after immediate implant placement

Aesthetic outcomes in immediate implants

Strategies to minimize hard and soft tissue changes in immediate implants

Justification

- OBJECTIVES.

.P. 35

- HYPOTHESIS

P. 39

- MATERIAL AND METHODS

P. 41

Patient selection

Sample size calculation

Surgical procedure

CBCT analysis

Investigators calibration 
Statistical evaluation

- RESULTS.

P. 50

- DISCUSSION.

P. 58

Hard tissue changes

Flap versus flapless approach

Influence of the buccal bone plate thickness

Soft tissue changes

Methodology

Limitations

- CONCLUSIONS.

- FUTURE PERSPECTIVES

P. 71

- REFERENCES

- ANNEXES

.P. 90

Approval of the thesis proyect

Approval of the Ethical Commitee

Patient's informed consent

Article accepted in Clinical Oral Implants Research 
SUMMARY 


\section{Introduction}

The placement of implants immediately after tooth extraction is the ideal treatment option in selected cases. However, previous studies have shown that placing an implant does not avoid the shrinkage of the alveolar ridge. The aims of the present investigation were to evaluate bone dimensions after immediate implant placement with simultaneous grafting of the buccal gap, to determine if initial buccal bone width had an influence on bone remodelling and to compare bone volume changes using a flap or a flapless approach after 6 months of healing.

\section{Material and methods}

This prospective study included patients who required an extraction and a subsequent immediate implant placement at a non-molar site. In those cases where tooth extraction was not feasible with a flapless approach (test group) a mucoperiosteal flap was carefully elevated (control group). After extraction, a cone beam computed tomography (CBCT) was taken. Then, an implant was placed and the buccal gap was grafted using anorganic bovine bone. After 6 months of healing, a second $\mathrm{CBCT}$ was performed. A blinded investigator superimposed both images and performed a series of measurements to determine bone volume changes between the two time points.

\section{Results}

Thirty-five patients were included in this study, 20 of which belonged to the test group. All together, the differences between baseline and 6 months in buccal plate height, lingual 
plate height and in ridge width at 2,4 and $6 \mathrm{~mm}$ were $0.48 \pm 1.35 ; 0.58 \pm 1.51 ; 0.64 \pm 0.81$; $0.59 \pm 1.36$ and $0.52 \pm 1.16$ respectively. Only a moderate correlation was observed between initial buccal plate width and buccal plate height at 6 months $(p=0.0001)$. No statistically significant differences were observed between flap and flapless approach.

\section{Conclusion}

A mean reduction of around $0,5 \mathrm{~mm}$ in height and width after placing immediate implants and filling the residual gap with anorganic bovine bone may be expected. No significant association between initial buccal bone width and ridge width at 6 months was seen. No statistically significant differences were found between the two treatment protocols although more ridge reduction was observed for the flap group. 
INTRODUCTION 


\section{INTRODUCTION}

Dental implants are nowadays a consolidated treatment option to replace missing teeth and restore the chewing function, speech, and aesthetics. They are inserted into the jawbone in order to support a dental prosthesis and remain stable due to the bone growth onto their surface. This phenomenon, also known as osseointegration, results in a direct, structural and functional connection between the living bone and the implant surface (Branemark et al. 1969). Implant therapy has surely been one of the most significant scientific progresses in dentistry over the past 50 years.

Traditionally, before placing dental implants, compromised teeth are removed and the extraction sockets are left to heal for several months. Unfortunately, alveolar ridge resorption after tooth extraction may considerably reduce the residual bone volume (Tan et al. 2012; Van del Weijden et al. 2009) and compromise the favorable implant positioning required for an optimal prosthetic restoration. The insertion of an implant immediately after tooth extraction was proposed in the late 1970s (Schulte \& Heimke, 1976) in order to avoid bone remodelling (Webitt \& Goldberg 1992; Watzek et at. 1995).

However, clinical and experimental evidence has shown that a reduction in height and width will still occur (Ferrus et al. 2010; Araújo et al. 2005, 2006). From an aesthetic point of view, these dimensional changes may lead to midfacial recession in the long term (Chen \& Buser 2014). It seems clear that a careful case selection -intact socket walls, a medium to thick biotype-, lingualized positioning of the implant and adequate primary stability as 
well as well as clinician's expertise are essential in order to achieve a stable aesthetic outcome (Lang et al. 2012; Chen \& Buser 2014).

In the past years different strategies have been developed in order to minimize the risk of mucosal recession. Some authors have tried to regenerate the missing bone between the implant surface and the socket walls using various bone augmentation techniques (Becker et al. 1994, Cosyn et al. 2011; Benic et al. 2012, Koh et al, 2011). Others have advocated thickening the soft tissues by means of a connective tissue graft at the time of surgery (Miglioratti et al. 2013). Last but not least, experimental studies in dogs have suggested that a flapless approach could minimize buccal bone resportion (Blanco et al. 2008).

The present investigation evaluates the effectiveness of some of the above-mentioned strategies in minimizing bone volume changes after immediate implant placement. 
BACKGROUND 


\section{BACKGROUND}

\section{Dimensional changes of the alveolar ridge after tooth extraction}

Tooth extraction has been the most frequent treatment in dentistry. Severe periodontal attachment loss, advanced caries and traumatisms are the main reasons for tooth removal. The alveolar bone receives blood supply mainly from three sources: the periodontal ligament, the bone marrow and the outer periosteum (Carranza et al. 1966). Since the alveolar bone walls are mostly comprised by cortical bone, the irrigation coming from the bone marrow is insufficient. Moreover, when a tooth is removed, blood supply coming from the periodontal ligament is interrupted. This limited vascular supply may lead to a bone resorptive process of the alveolar ridge once a tooth is removed. Araújo et al. reported a reduction in height and width especially on the buccal wall (Araujo et al. 2005). The outcomes of a recent systematic review showed more horizontal bone loss (range: $29-63 \% ; 3,79 \pm 0,23 \mathrm{~mm}$ ), than vertical reduction (range: 11 $22 \% ; 1,24 \pm 0,11 \mathrm{~mm}$ on buccal sites) in human studies after tooth extraction. During the first 3 months, a horizontal reduction on $32 \%$ was observed, while it reached up to $63 \%$ at 6 months. Thereafter, a more gradual decrease in volume was observed (Tan et al. 2012). Furthermore, a greater reduction was seen in the buccal and lingual aspects when compared to the mesial and distal walls (Tan et al. 2012; Van der Weijden et al. 2009). 
With respect to soft tissues changes, one study (Iasella et al. 2003) observed a mean soft tissue gain of $0.4-0.5 \mathrm{~mm}$ in the buccal and lingual aspects and $2.1 \mathrm{~mm}$ in thickness over the alveolar crest 6 months after tooth removal.

In summary, although ridge resorption may not always be clinically evident due to the soft tissue thickness, a reduction especially in width may be expected after several months of healing. 


\section{Timing of implant placement}

The standard of care in implant dentistry is to wait for the alveolar ridge to heal for several weeks or months after tooth extraction to ensure a sufficient amount of mature bone to hold the implant in place. However, in order to shorten the treatment time thereby increasing our patients' satisfaction, other protocols have been proposed. Hämmerle et al. (2004) made the following classification of implant placement timing according to hard and soft tissue healing after tooth extraction:

- Type 1. Immediate implant placement. Implants are placed immediately following tooth extraction and as part of the same surgical procedure.

- Type 2. Early implant placement. Implants are placed after complete soft tissue coverage of the socket, at 4 to 8 weeks.

- Type 3. Implants are placed after substantial clinical and/or radiographic bone fill of the socket, at 12 to 16 weeks.

- Type 4. Implants are placed at a completely healed site, after 16 weeks.

The benefits and drawbacks of these timing protocols have been matter of discussion in the last years (Hämmerle et al. 2004; Chen et al, 2004).

Advantages and limitations of immediate implants will be explained in detail in the following section. 
Early implant placement takes place at soft tissue closure at a time point where the socket walls are still present and the resorptive process has not yet finished. Implants may be placed and primary soft tissue closure can be more easily achieved without an extensive advancement of the flaps because of increased soft tissue availability. This is especially interesting in those cases where guided bone regeneration is needed (Buser et al. 2008a, 2008b, 2011; Cosyn \& De Rouck, 2009). Secondly, in those cases of previous periapical pathology, resolution of the lesions may be expected. However, it must be taken into account that this aproach requires high surgical skills because the site morphology may complicate an optimal placement. A recent systematic review comparing delayed (types 3 and 4) versus early implant placement (type 2) observed no differences between the two timing protocols in terms of implant survival. The results of the meta-analysis showed a greater mean reduction of $13,11 \%$ and $19,85 \%$ in height and width respectively in the delayed implant placement group. These data should be interpreted cautiously since only two studies were included. Patients' satisfaction and aesthetic appearance was reported to be higher in the type 2 group two years after but this difference disappeared in longer follow-up periods (Sanz et al. 2011).

At late implant placement (types 3 and 4) the ridge is clinically healed. There is a substantial bone fill of the socket that facilitates implant placement and soft tissues are mature, facilitating flap management. On the other hand, the treatment time is increased and the varying degrees in ridge reduction may require additional bone regeneration.

Besides the advantages and limitations of these four approaches, it would be interesting to asses if it has an impact on implant survival and success. In this sense, one systematic review observed no differences between the different timing protocols in terms of implant survival, but the few included studies were considered to have a high risk of bias (Esposito et al. 2010). A meta- 
analysis reported a survival rate from $93.6-97.5 \%$ for immediate and early implant placement and $92.8 \%$ for conventionally inserted implants after 1 year (Hartlog et al. 2008).

Hof et al. (2015) evaluated the aesthetic outcomes after immediate, early and delayed implant placement in the anterior maxilla. They excluded all cases in which soft tissue grafting was performed. At a mean follow-up of 4.5 years, a mean periimplant bone loss of $1.6 \mathrm{~mm}$ was observed and no statistically significant differences between groups were detected. With respect to aesthetic outcomes, significant more papilla formation was observed in the delayed and immediate placement groups than in the early placement group. No statistically significant differences between treatment groups were detected for the pink esthetic score, the white esthetic score and the subjective esthetic score. Patients overall satisfaction using the visual analogue scale was $95 \%, 84 \%$ and $80 \%$ immediate, early and delayed implant groups respectively. Similarly, Cosyn et al. (2013) observed similar pink esthetic and white esthetic scores in the delayed and immediate implant placement groups. 
Immediate implant placement

Forty years ago, Schulte and Heinke (1976) placed 54 implants immediately after tooth extraction and followed the patients for 2 years and a half. Only one implant was lost during that healing period. Thirty years after, Paolantonio et al. (2001) compared histological sections of immediate implants and delayed implants and observed that they had a similar degree of osseointegration. Further histological observations on animal models have confirmed new bone formation from a quantitative and qualitative point of view (Vignoletti et al. 2012).

Immediate implant placement clearly reduces the number of surgical procedures and treatment time. However, it is a very technique-sensitive procedure since the alveolar morphology may complicate an adequate implant position and primary stability. Additionally, a discrepancy between the implant and the socket anatomy is frequently encountered (Hämmerle et al. 2004; Chen et al. 2004).

Nevertheless, the survival rates of type I implants seem to be comparable to the $97.2 \%$ at 5 years follow-up described for delayed single implants (Jung et al. 2012). Lang et al. (2012) performed a systematic review that included 2908 immediately placed implants with a mean follow-up of 2 years. The reported survival rate was $98.4 \%$ at two years, $97.5 \%$ at 3 years. The influence of implant position, reason of extraction, loading protocol and postoperative antibiotic therapy on failure rate was evaluated. Implants placed in the maxilla had a lower survival rates than implants placed in the mandible, although the differences were not statistically significant. With respect to implant loading, there was a non-statistically significant trend towards a greater failure rate when immediate loading was performed. Reason of tooth extraction (periodontitis or not) was not also related to implant loss. The antibiotic regimen on the other hand did have an 
influence on implant survival. A post-operative antibiotic use decreased the annual failure from $1.87 \%$ (no postoperative antibiotics) to $0.51 \%$.

As it has been previously mentioned, one important reason for tooth extraction is advanced caries, which may lead to the infection of the pulp and end up in a periapical infection. Placing immediate implants on sites with previous periapical pathologies has been a concerning issue but some recent studies have shown similar survival rates to those implants inserted in healthy areas (Jung et al. 2013; Lindebom et al. 2006). Hence, survival rates of 92-100\% were reported in a recent systematic review (Corbella et al. 2013). 


\section{Hard and soft tissue changes after immediate implant placement}

It was first thought that, placing an implant just after tooth extraction, when the healing process has not yet started would avoid bone resorption (Webitt \& Goldberg 1992; Watzek et at. 1995). However, evidence from animal and human studies have shown that implant installation does not interfere with bone remodeling (Boticelli et al. 2004, 2006; Araujo et al. 2005, 2006; Sanz et al. 2009; Ferrus et al. 2010; Tomasi et al. 2010; Discepoli et al. 2014).

Araujo $(2005,2006)$ carried on a study on a beagle dog model to evaluate the modeling process of the alveolar process after inserting type I implants. After raising a full-thickness flap and removing the distal roots of the selected teeth on the right side of the mandible, they placed immediate implants and a healing abutment. Two months after, they repeated the same process on the left side. One month after this last procedure, animals were sacrificed and biopsies were obtained for histological analysis. At four weeks of healing, the space between the implant surface and the bony wall was occupied by connective tissue and woven bone. At premolar sites, buccal bone thickness had resorbed at the implant shoulder level and was $0.4 \pm 0.3 \mathrm{~mm}$ and $1 \pm$ $0.2 \mathrm{~mm}$ thick at 1 and $3 \mathrm{~mm}$ below the implant shoulder. The lingual plate was $1.4 \pm 0.8 \mathrm{~mm}$ at the implant shoulder level and $1.8 \pm 0.5$ and $2.1 \pm 0.5$ at the lower levels. On the other hand, 3 months after tooth extraction there was no bone at the implant shoulder level and $1 \mathrm{~mm}$ below it, and was $0.5 \pm 0.3 \mathrm{~mm}$ thick at $3 \mathrm{~mm}$. The lingual bone wall presented a similar thickness as in the 1month observation. In summary, it was demonstrated that the gap between the implant and the bone walls was occupied due to bone fill and bone resorption. On the buccal aspect a reduction of more than $2 \mathrm{~mm}$ in height was observed. 
Moreover, animal studies have compared dimensional ridge alterations after placing immediate implants with spontaneous healing after tooth extraction (Vignoletti et al. 2012; Discepoli et al. 2014). At eight weeks of healing, the buccal bone wall reduction at control sites was $0.18 \pm$ $0.08 \mathrm{~mm}$ while at implant sites it was reported to be $0.94 \pm 0.12 \mathrm{~mm}$, in other words, two or three times greater. The vertical distance between the buccal and the lingual bone increased during the healing period at the immediate implant sites while it kept unchanged at the natural healing sites (Discepoli et al. 2014). Both investigations concluded that, immediate implant placement not only does not avoid dimensional changes of the alveolar ridge but even results in a greater resorption, possible caused by the additional surgical trauma.

Boticelli et al. (2004) evaluated hard-tissue changes of 21 implants placed in fresh extraction sockets in humans. At re-entry 4 months after implant placement, $56 \%$ and $30 \%$ reduction in ridge with were observed in the buccal and lingual walls respectively. Vertical bone reduction was reported to be around $0.5 \mathrm{~mm}$ at the buccal, lingual, mesial and distal aspects.

Covani et al. (2007) made similar observations at 6 months re-entry after placing 20 immediate implants. They registered a mean distance between the implant shoulder and the first bone to implant contact of $0.9 \pm 0.7 \mathrm{~mm}, 0.8 \pm 0.7 \mathrm{~mm}, 1.2 \pm 0.5 \mathrm{~mm}$ and $0.3 \pm 0.5 \mathrm{~mm}$ at mesial, buccal, distal and lingual sites respectively. Rossi et al. (2013) have further confirmed these outcomes on a CBCT study on 12 consecutive immediate implants. At four months, ridge height reduced 0.9 $\pm 0.8 \mathrm{~mm}$ buccally, $0.6 \pm 0.7 \mathrm{~mm}$ lingually, $0.3 \pm 1.0 \mathrm{~mm}$ mesially and $0.8 \pm 0.6 \mathrm{~mm}$ distally. It is interesting to notice how both studies observed less reduction on the mesial wall. Rossi et al. (2013) suggested that some of the included cases did not have a neighboring tooth distally, which has been observed to result in a greater bone loss than sites bordered by teeth (Boticelli et al. 2008). 
A recent meta-analysis revealed in type I implants with no simultaneous bone grafting, a weighted mean horizontal reduction in the buccal bone plate of $1.32 \mathrm{~mm}$ and $0.86 \mathrm{~mm}$ vertically. On the palatal aspect, a weighted mean reduction of $0.62 \mathrm{~mm}$ and $0.50 \mathrm{~mm}$ in width and height respectively was observed at 4 to 12 months after implant placement (Lee et al. 2014).

Since a marked ridge resorption of the bone walls have been observed after immediate implant placement, Ferrus et al. (2010) and Tomasi et al. (2010) evaluated several factors that could be related with this phenomenon. They analyzed patient-related factors, cause of tooth extraction, implant location (anterior/posterior), size of the buccal gap and buccal plate thickness. They observed that age and smoking had an influence on bone remodeling. Thus, older subjects tended to less vertical bone fill of the gap and smokers less reduction in the horizontal dimension of the gap. Secondly, more bone resorption was observed when implants were placed at incisor sites when compared to premolar sites. Whether tooth extraction was performed due to advanced periodontal attachment loss or not did not seem to have have an effect on hard-tissue remodeling. With respect to the socket morphology, when the size of the existing gap between the implant surface and the bone wall was less than $1 \mathrm{~mm}$, a greater reduction of the horizontal defect was seen. The presence of a thick buccal wall resulted in greater bone fill of the gap and less vertical resorption.

The presence of an adequate amount of buccal bone support is essential to avoid midfacial soft tissue recession and have an adequate soft tissue contour in the long term (Grunder et al. 2005). As we have seen previously, if an implant is placed in a fresh extraction socket vertical buccal bone resportion might take place specially if it is less than $1 \mathrm{~mm}$ thick. It has been observed that the facial bone wall in the anterior maxilla is mostly thin and ranges from 0.5 to $0.7 \mathrm{~mm}$ (Braut et al. 2011). Therefore, a higher probability of midfacial recession can be expected in immediate 
implants in the anterior area (Chen \& Buser, 2009). Lang et al. (2012) have reported that, although major soft tissue changes occur during the first six months after implant placement, they may continue after this period. Interproximal papillae tend to increase with time but midfacially the soft tissue margin rather moves in an apical direction.

Thin gingival biotypes have shown to be more susceptible to midfacial recession. Kan et al. (2003) studied the dimensions of the periimplant mucosa around immediate implants and observed that its dimensions were significantly increased at thick biotypes with respect to thin biotypes. 


\section{Aesthetic outcomes in immediate implants}

The prevalence of advanced recession $(>1 \mathrm{~mm})$ after immediate implant placement was systematically addressed by Cosyn et al. (2013). Slight interproximal recession $(<1 \mathrm{~mm})$ was reported in 11 out of the 13 selected studies. However, two studies observed a complete papilla fill in $70 \%$ of the cases. The prevalence for advanced midfacial recession was $<10 \%$ in patients with an intact buccal bone wall and a thick biotype. On the contrary, Chen \& Buser (2009) concluded that midfacial recession was a common finding after immediate implant placement. They reported a frequency of $8.7-40.5 \%$ of advanced midfacial recession $(>1 \mathrm{~mm})$. When analyzing the outcomes of both systematic reviews, it has to be considered that Cosyn et al. (2013) only included studies in which implants had been placed in intact sockets, whereas Chen \& Buser (2009) included all types of sockets.

With respect to the influence of gingival biotypes, Evans et al. (2008) observed a mean recession of $0.9 \pm 0.78 \mathrm{~mm}$ after a mean follow up of 18 months. A slightly greater recession was observed in thin biotypes than in thick biotypes $(1 \pm 0.9 \mathrm{~mm}$ and $0.7 \pm 0.57 \mathrm{~mm}$ respectively). Chen \& Buser (2009) also observed a lower frequency of advanced gingival recession in thick biotypes.

Boticelli et al. (2008) reported slightly greater midfacial recession at implants placed in the mandible $(1.2 \pm 1.8 \mathrm{~mm})$ than at maxillary sites $(0.2 \pm 1 \mathrm{~mm})$. 
Strategies to minimize hard and soft tissue changes in immediate implants

As we have seen, the shrinkage of the alveolar ridge after immediate implant placement still represents a special challenge in daily practice. As oral soft tissues follow the underlying bone contour, an intact buccal bone wall seems to reduce the risk of midfacial recession (Cosyn et al, 2013; Vignoletti \& Sanz 2014). Therefore an adequate case selection, meaning intact socket walls, is essential to limit the occurrence of esthetic failures. Additionally, different strategies have been developed in the last years in order to more predictably achieve an esthetic outcome.

Implant position

A correct three-dimensional position of the implant is essential in order to avoid a esthetic complications. Evans et al. (2008) observed that buccally placed implants showed three times more recession than lingually places implants: $1.8 \pm 0.83 \mathrm{~mm}$ versus $0.6 \pm 0.55 \mathrm{~mm}$. Similarly, Tomasi et al. (2010) observed in a multilevel analysis how every $1 \mathrm{~mm}$ increase of the implant position towards the buccal aspect resulted in a resorption of the buccal bone wall of $0.22 \mathrm{~mm}$. Lee et al. (2014) observed on CBCTs after 6 months how the buccal plate was preserved when implants were lingually positioned.

Even the healing cap buccolingual position may increase the prevalence of recession. In a prospective clinical study the frequency of gingival recession was $58.3 \%$ in sites where the healing cap was buccally placed and $16.7 \%$ where they were lingually placed (Chen et al. 2007). 
The influence of the apicocoronal position of type 1 implants in relation to the alveolar crest has also been evaluated. Thus, Koh et al. (2013) found no differences in hard tissue changes between immediate implants placed crestally and subcrestally with respect to the lingual bone wall. However, in the subcrestal group, a significant gain in keratinized tissue was observed. Cordaro et al. (2011) also failed to find any differences on bone levels evaluated on periapical radiographs following a crestal and subcrestal insertion of the implants.

Implant design

A tapered implant design has been recommended in type I implants to increase primary stability and to reduce the need of additional bone augmentation. However, Lang et al. (2007) compared tapered and cilyndrical Straumann ${ }^{\circledR}$ immediate implants and observed no differences between groups regarding primary implant stability or bone augmentation. With respect to hard tissue changes, Sanz et al. (2010) placed 50 tapered and 49 cylindrical implants in fresh extraction sockets. At 4 months, a surgical re-entry was performed to evaluate the dimensional changes.

Some authors (Canullo \& Rasperini 2007; Pieri et al. 2011) recently suggested that applying the platform-switch concept to immediate implants would counteract bone resorption of the buccal plate. Canullo \& Rasperini (2007) evaluated clinically and radiographically implants that had been immediately placed and connected to a narrow diameter abutment. After two years, a radiographic bone loss of $0.76 \mathrm{~mm}$ and $2.8 \mathrm{~mm}$ of probing pocket depth were observed. They even reported a coronal displacement of the soft tissue margin of $0.25 \mathrm{~mm}$. In this sense, Pieri and coworkers (2011) compared hard and soft tissue alterations at immediate implants with a platform-switch connection and implants with conventional abutments. At one year, bone loss 
was significantly greater in the control group $(0.51 \pm 0.24 \mathrm{~mm})$ than in the test group $(0.2 \pm$ 0.17). However, marginal soft tissue levels did not differ between groups.

\section{Soft tissue grafts}

The gingival biotype has been shown to be an important predictor of future midfacial recession. Hence, thick biotypes have shown more soft tissue stability over time. (Evans et al. 2008; Chen $\&$ Buser, 2009). Therefore, the simultaneous placement of soft tissue grafts has been proposed in order to minimize the risk of recession.

A recent randomized clinical trial compared immediate implants with or without simultaneous soft tissue grafting over a 2-year follow up. At two years, control sites showed a mean recession of $0.71 \mathrm{~mm}$ and $1.0 \mathrm{~mm}$ of gingival thickness whereas in the test group, mean recession was $0.4 \mathrm{~mm}$ and gingival thickness $1.5 \mathrm{~mm}$, respectively. The differences between groups were statistically significant. An increased gingival thickness reduced the probability of unaesthetic transparencies and midfacial recession and was directly correlated with higher pink esthetic score (PES). While in the entire test group all thin biotype cases obtained a satisfactory PES value only $75 \%$ of the control group obtained sufficient PES values. Good PES was obtained in $0 \%$ and $57 \%$ of the thin biotype cases in the control and test groups respectively (Miglioratti et al. 2013).

Bianchi \& Sanfilippo (2004) observed a better emergence profile as well as an increased gingival thickness at immediate implants that received a subepithelial connective graft with respect to the 
control sites at 1 to 9 years. Additionally, grafted sites showed less probing pocket depth than control sites, thereby showing more periimplant soft tissue stability.

\section{Provisionalization}

Immediate implant placement has clearly increased our patients satisfaction due to the reduced treatment time and number of surgical procedures. If this approach is combined this with an immediate aesthetic restoration their expectations will be fulfilled (Atieh et al. 2009). This technique was first described by Wöhrle (1998) and in the last years many authors have reported successful outcomes (Kan et al. 2003; De Rouck et al. 2009; Roe et al. 2012; Tarnow et al. 2014; Morimoto et al. 2014) .

In order to determine if provisionalization reduces bone resorption, fifty immediate implants were randomly provisionalized following an immediate or a delayed protocol. The authors observed an additional midfacial recession of $0.75 \mathrm{~mm}$ in the conventionally restored treatment group at one year (De Rouck et al. 2009). Similarly, Tarnow et al. (2014) retrospectively analyzed on study casts immediate implant cases where a provisional prosthesis was placed simultaneously with cases where a healing abutment was inserted. The ridge contour almost kept unchanged in those cases where implants were immediately restored. 


\section{Bone augmentation}

The misfit between the extraction socket and the implant results in a residual gap. Although, previous studies (Ferrus et al. 2010) have observed new bone formation in the existing gap at reentry, when the gap size was greater than $1 \mathrm{~mm}$, bone fill of the defect tended to be incomplete. Therefore, filling the existing space between the implant surface and the buccal bone wall has been proposed.

Chen et al. (2007) performed a randomized clinical trial in which immediate implants either received a xenograft, a xenograft plus a collagen reabsorbable membrane or no graft (control group). At one year, they observed a horizontal bone resorption of $48.3 \pm 9.5 \%$ in the control group whereas the xenograft group and the xenograft plus membrane group presented $15.8 \pm$ $16.9 \%$ and $20 \pm 21.9 \%$ horizontal reduction respectively.

A retrospective study compared ridge dimensions on study casts after single tooth replament with immediate implants where simultaneous bone augmentation was performed with cases in which sites were left to heal spontaneously. They observed that significant reduction in width at control sites when compared to augmented areas (Tarnow et al. 2014).

A systematic review analyzed the effectiveness of performing a bone augmentation technique in minimizing dimensional changes at implant sites on 11 studies. On sites with immediate implant placement alone a horizontal reduction of $1.02-1.10 \mathrm{~mm}$ and a vertical reduction of $0.54-1.12 \mathrm{~mm}$ was seen. On the other hand, at grafted sites, vertical change was reported to range from 0.79 in two randomized clinical trials and $1.79 \mathrm{~mm}$ in 2 cohort studies. Due to the lack of well designed 
studies, the authors were not able to draw firm conclusions on the additional benefit of simultaneous bone grafting at type I implants (Clementini et al. 2015).

\section{Surgical procedure}

A thorough surgical approach is mandatory when dealing with the anterior maxillary area, but specially if an immediate implant placement is planned after tooth extraction. As it has been previously stated, intact socket walls are a pre-requisite to achieve a predictable aesthetic outcome. Therefore, the extraction of the hopeless tooth has be performed gently to minimize the trauma on hard and soft tissues.

The buccal cortical plate is mostly comprised by bundle bone and its vascular supply is reduced after tooth removal. Raising a flap implies the separation of the outer periosteum, which will cause an acute inflammatory response and result in the resorption of the exposed bone surface (Fickl et al. 2011). Therefore, flapless implant placement has been proposed.

In this sense, some investigations on an animal model have been performed to compare a flap and a flapless approach for immediate implant placement (Caneva et al. 2010; Blanco et al. 2008). Blanco et al. (2008) placed 20 immediate implants on beagle dogs and compared hard tissue alterations of sites where a flap was raised (control) with sites where a flapless surgery (test) had been carried out. At three months healing, the buccal bone plate was located $0.82 \mathrm{~mm}$ apical to the implant shoulder in test sites and at $1.33 \mathrm{~mm}$ in control sites, but these differences were not statistically significant. In order to further elucidate this question, Caneva et al. (2010) performed a similar investigation in a canine model. At 4 months of healing, a buccal plate 
reduction of $1.7 \mathrm{~mm}$ in experimental sites and $1.5 \mathrm{~mm}$ in control sites was seen. The authors concluded that a flapless approach did not result in a minor vertical bone reduction.

The effectiveness of some of these strategies in preserving the original bone dimensions were evaluated by Slagter et al (2014). The regression analysis showed a direct relation between raising a flap a delayed provisionalization and using a connective tissue graft with $>0.5$ bone level change. The authors were not able to report on esthetic results and patient-based outcomes due to lack of available information. 


\section{JUSTIFICATION}

As it has been widely described above, immediate implant placement does not counteract hard and soft tissues of the alveolar ridge. These alterations seem to be influenced by some anatomical factors such as buccal bone plate thickness and gingival biotype. Hence, thin scalloped biotypes with an underlying thin buccal plate seem to be more susceptible to a reduction in height of the alveolar plate and thus, to midfacial recession in the long term.

Immediate implant placement with simultaneous bone augmentation has been proposed to minimize midfacial recession but evidence regarding hard tissue alterations is still missing. It is still not known whether initial buccal plate thickness has an influence on ridge reduction in height and width when this combined procedure is performed. Furthermore, the additional benefit of a flapless surgery remains unclear. 
OBJECTIVES 


\section{OBJECTIVES}

The aims of the present study were:

- To evaluate alveolar bone dimensions after immediate implant placement in sockets with an intact buccal plate, grafting the gap between the implant and the socket wall with anorganic bovine bone graft

- To compare bone volume alterations using a flap or a flapless approach.

- To determine if initial buccal plate width has an influence on hard tissue changes. 
HYPOTHESIS 


\section{HYPOTHESIS}

Primary objective:

$\mathbf{H}_{\mathbf{0}}$ : Flap elevation will not result in a greater reduction in height and width of the alveolar ridge at 6 months healing.

$\mathbf{H}_{1}$ : Flap elevation will result in a greater reduction in height and width of the alveolar ridge after 6 months of healing.

Secondary objective:

$\mathbf{H}_{\mathbf{0}}$ : Initial buccal bone width will not be related to ridge dimensions at 6 months of healing.

$\mathbf{H}_{1}$ : Initial buccal bone width will be associated to ridge dimensions at 6 months of healing. 
MATERIAL AND METHODS 


\section{MATERIAL AND METHODS}

\section{Patient selection}

This prospective study was performed between January 2012 and January 2014 at the Dental Clinic of the University of Padova. The study was approved by the University of Padova Ethical Committee (Ref. 2571-P, 12-03-2012) and was in accordance with the Helsinki Declaration of 1975, as revised in 2008. Written informed consent was obtained from all the subjects included in the study.

The patient inclusion criteria were as follows:

- dentate patients having one non-molar tooth planned for extraction.

- full mouth plaque score (FMPS) and full mouth bleeding scores (FMBS) $<25 \%$ at study baseline.

- eventual loss of attachment limited only to areas different from the sites included in the study.

- primary stability of at least $35 \mathrm{~N}$ at implant placement.

Patient exclusion criteria were as follows

- patient with medical history in which any dental intervention would be contraindicated.

- any local or systemic disease, condition or medication that might compromise healing and/or affect the periodontium. 
- smoking habit.

- inability or unwillingness to return for follow-up visits.

- presence of a dehiscence or fenestration in the buccal wall after tooth extraction.

\section{Sample size calculation}

Sample size calculation was performed before patient enrolment and was based on the main study outcome: bone dimensions changes at 6 months. A paired difference in bone width of $1 \mathrm{~mm}$ between groups was considered clinically relevant. Assuming an alpha risk of 5\% and a beta risk of $20 \%$ in a two-sided test, a total of 30 patients (15 subjects in each group) were necessary to recognize as statistically significant a difference equal or greater than $1 \mathrm{~mm}$. A common standard deviation between $1.1 \mathrm{~mm}$ was considered (Ferrus et al. 2010). 


\section{Surgical procedures}

One hour before the surgical procedure, patients began a prophylactic antibiotic regimen consisting of $2 \mathrm{~g}$ of amoxicillin and clavulanic acid (Augmentin ${ }^{\circledR}$, Roche, Milan, Italy). All procedures were performed under local anesthesia (articaine chlorhydrate $4 \%$ and adrenaline 1:100000 -Alfacaina N, Weimer Pharma, Rastat, Germany-) and sedation was arranged if needed. First, tooth extraction was performed in a gentle way to minimize the mechanical trauma onto the surrounding bone. If tooth extraction was not feasible with a flapless approach due to root fracture or a complete destruction of the coronal third of the root, a mucoperiosteal flap was carefully elevated. The periodontal ligament attached to the bone in the socket walls was left undisturbed. If present, granulation tissue was carefully removed from the socket.

Immediately after the extraction a CBCT (Kodak 9000, Kodak Dental System, Rochester, New York) was taken in order to evaluate the integrity of the facial wall of the socket. If a fullthickness flap was needed in order to remove the tooth, the patient was allocated to the control group. Otherwise, when flapless extraction was feasible, the patient was allocated to the test group.

\section{Control Group (flap approach)}

An immediate implant installation (NT Osseotite ${ }^{\circledR}$ 3i, Palm Beach, USA) was performed. The existing gap between the implant and the facial wall was filled with small granules of anorganic bovine bone graft (Bio-Oss ${ }^{\circledR}$, Geistlich Pharma AG, Wolhusen, Switzerland). No membrane was used. A healing abutment was placed and the flap sutured around it after being repositioned (Figure 1). 


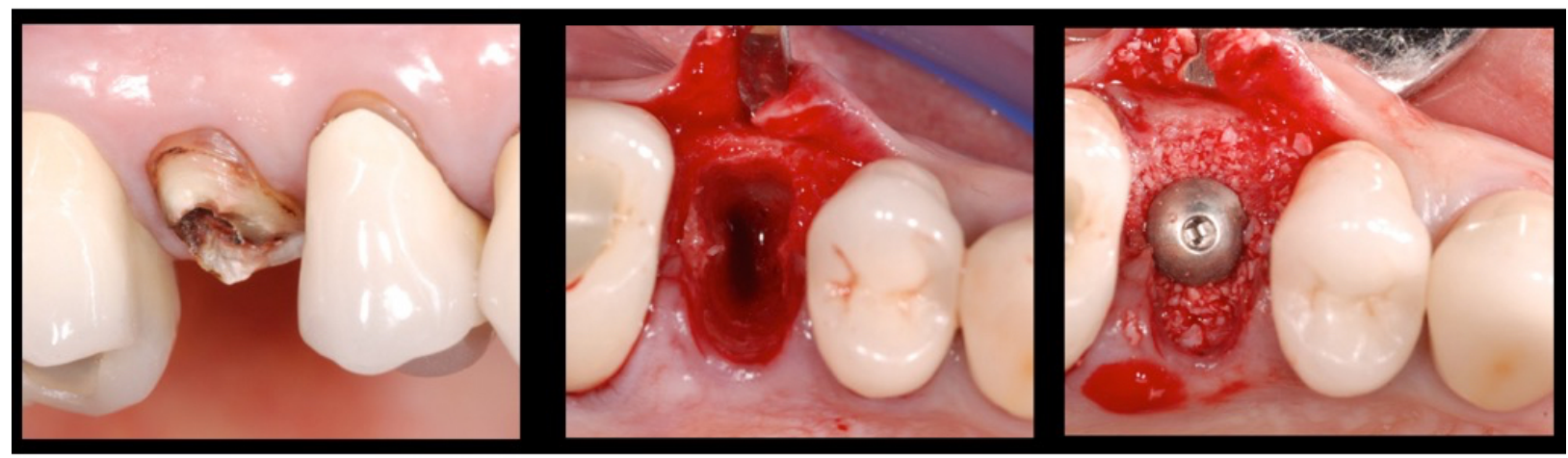

Figure 1. Implant placement in the flap group.

Test Group (flapless approach)

An immediate implant installation was performed with a flapless approach. Again, the gap was

filled with small granules of anorganic bone substitute graft and a healing abutment was placed

(Figure 2).

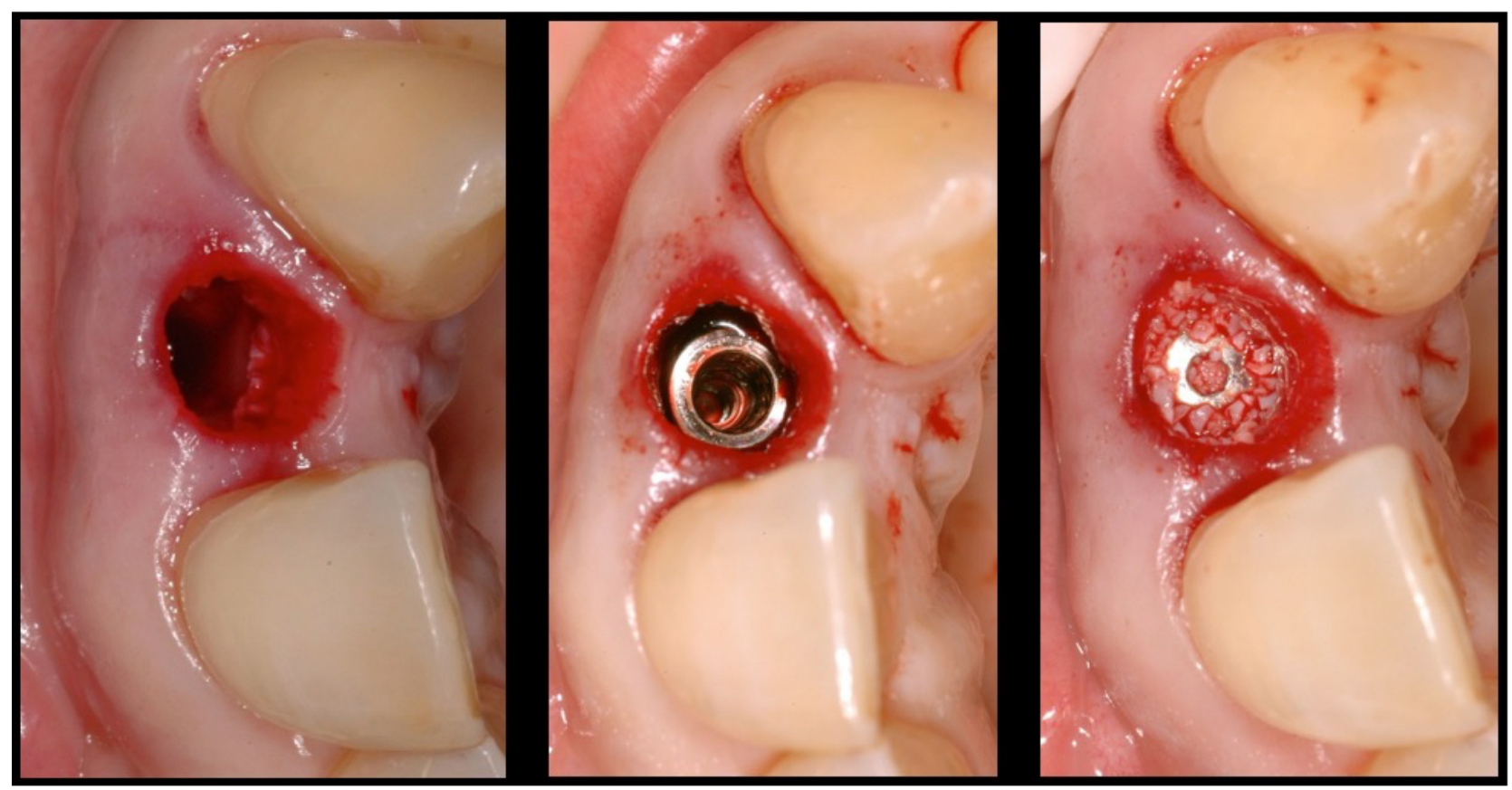

Figure 2. Implant placement in the flapless group. 
All implants were placed $3 \mathrm{~mm}$ apical to the margin of the prosthetic crown and oriented towards the cingulum of the future implant supported crown of incisors and canines or the center of the oclusal aspect in the case of premolars.

Post-operative care

A Maryland provisional prosthesis was placed immediately after the surgery. Patients received antibiotic therapy with 1000/62,5 amoxicillin/clavulanic acid (Augmentin Plus ${ }^{\circledR}$, Roche, Milan, Italy) twice a day for 6 days. Ibuprofen $400 \mathrm{mg}$ was prescribed three times per day if needed.

Follow-up visits.

Suture removal was scheduled 1 week after surgery. Patients were then scheduled for a follow up visit 1, 3 and 6 months after surgery. By the end of the fifth month, all implants were loaded.

At 6 months, a second CBCT was performed. At this point, a clinical evaluation was made and standardized periapical radiographs were taken in order to evaluate the peri-implant baseline bone levels.

Surgical and prosthetic complications were recorded any time they occurred. Patients were recalled at 3 and 6 months after prosthesis delivery. 


\section{CBCT analysis}

A first CBCT (Kodak 9000, Kodak Dental System, Rochester, New York) (CBCT1) was taken immediately after extraction and before implant placement and a second CBCT (CBCT2) was taken at 6 months at final prosthesis delivery. The 3D reconstructions of both CBCTs were superimposed using Simplant Pro ${ }^{\circledR} 2011$ (Dentsply Spain, S.L.) according to the technique described by Jung et al. (2013). At least three anatomical reference points were established on each 3D image in order to match CBCT1 and CBCT2 (Figure 3). A manual adjustment was applied when necessary to fit small discrepancies at the final superposition. The measurements were made at baseline and at 6 months using the same reference points and lines (Figure 4). A horizontal reference line was drawn at the base of the socket and a perpendicular line from this reference was used in the centre of the extraction socket as the vertical reference. The baseline buccal plate width (BW) was assessed at $1 \mathrm{~mm}, 3 \mathrm{~mm}$ and $5 \mathrm{~mm}$ below the most coronal aspect of the buccal bone crest in a coronal section of CBCT1. Height was measured from the most coronal aspect of the buccal and lingual bone crest in CBCT1 and CBCT2 to the horizontal reference line. Then, the difference between measurements was calculated to express the dimensional change in height between groups. The width of the ridge was measured in CBCT 1 and CBCT 2 at $2 \mathrm{~mm}, 4 \mathrm{~mm}$ and $6 \mathrm{~mm}$ below the most coronal aspect of the buccal bone crest of CBCT1 in a coronal view, and then the width difference was calculated for each group and expressed in $\mathrm{mm}$ to assess the width dimensional changes at 6 months. 


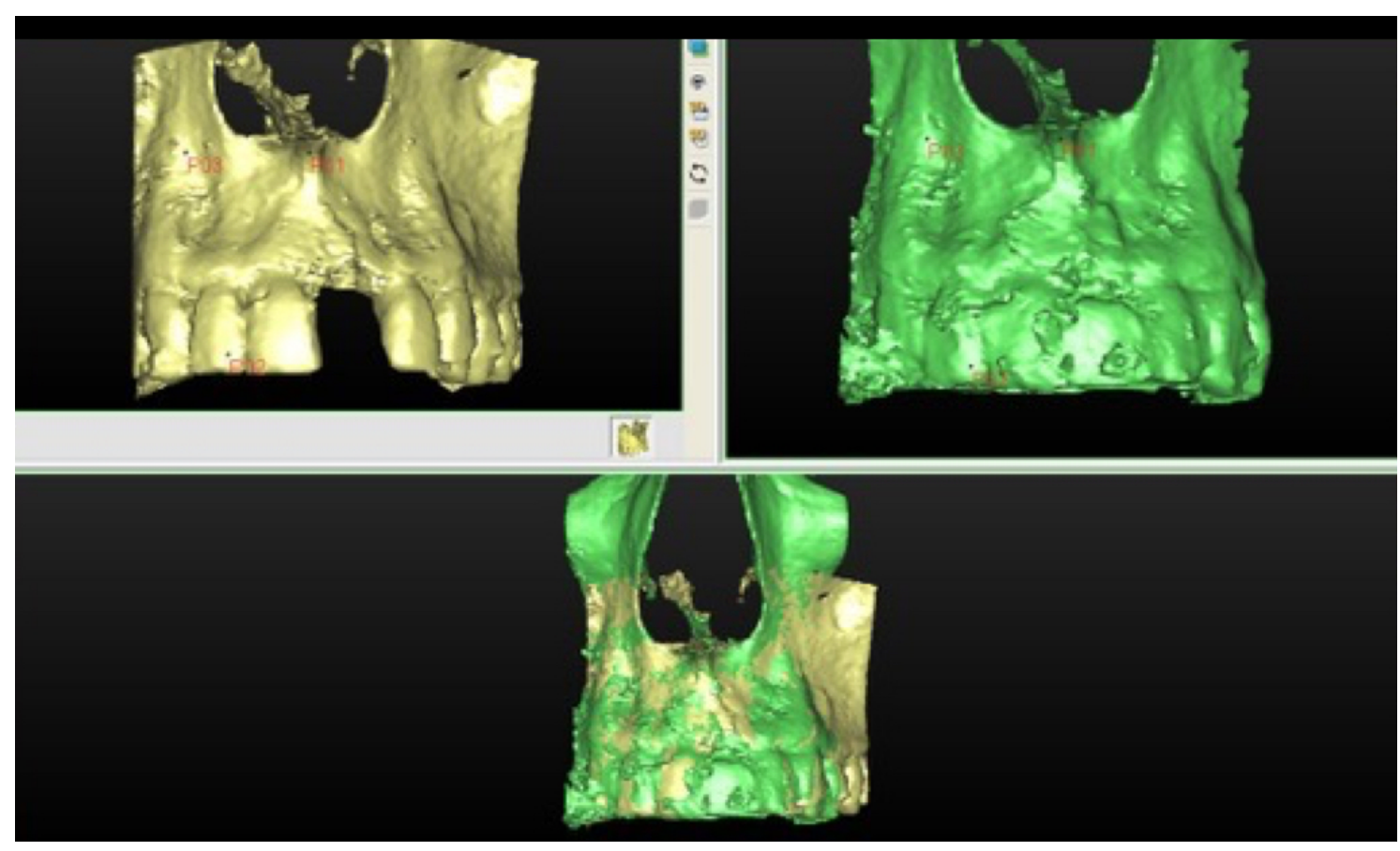

Figure 3. Superposition of $\mathrm{CBCT} 1$ and $\mathrm{CBCT} 2$ using the infraorbital foramen, the anterior nasal spine and the incisal edge of 11 as a reference.

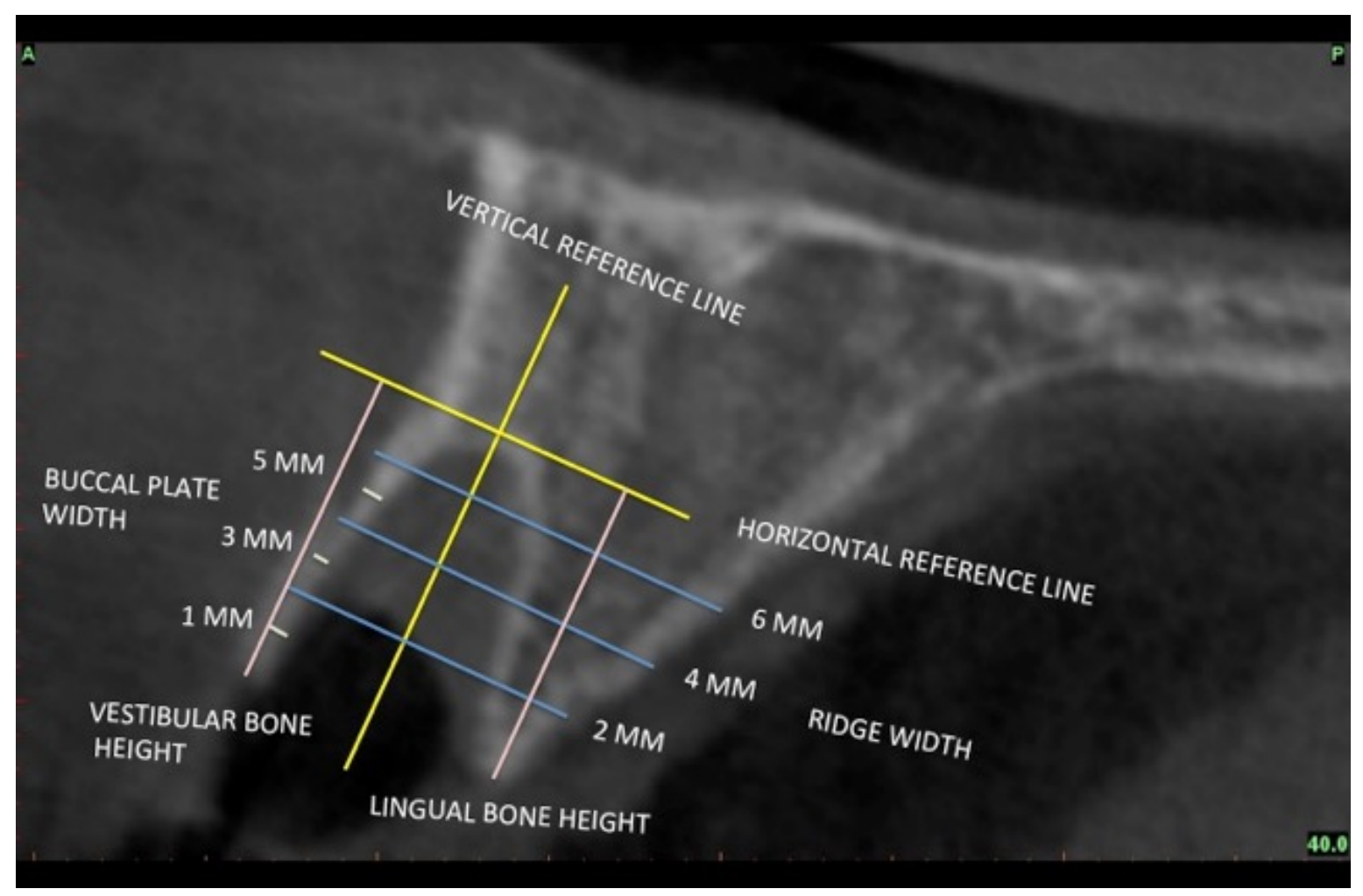

Figure 4. Measurements taken on the CBCT scans. 


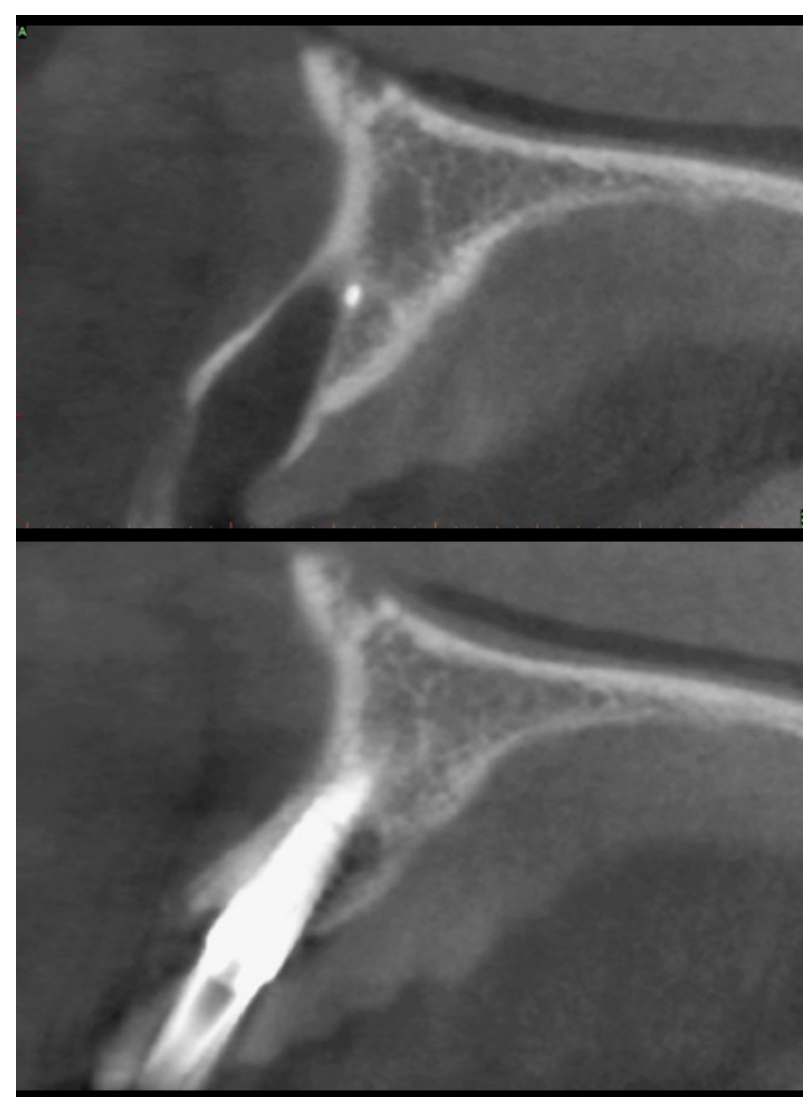

Figure 4. CBCT1 and CBCT2 in the flap group.

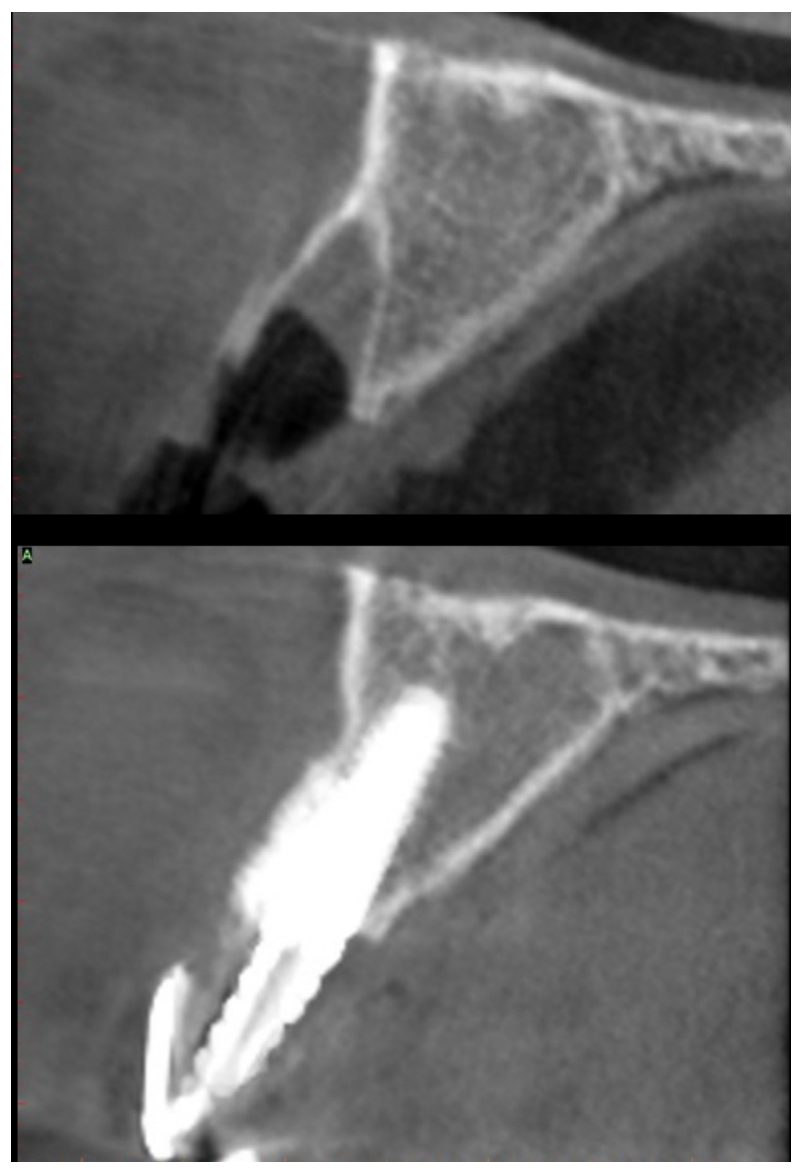

Figure 5. CBCT1 and CBCT2 in the flapless group. 


\section{Investigators calibration}

An examiner (D.J.) was trained on the use of the proposed measurements systems and was blinded with respect to the treatment group (flap and flapless). All needed clarifications were provided before the study. Each selected site was evaluated twice, independently and blindly. Bone level changes were recorded for each treated site. There was no time restriction during the procedure.

Intra-examiner reliability was conducted by the repeated examination of the buccal plate thickness at 1, 3 and $5 \mathrm{~mm}$ in 5 patients, 24 hours apart, before beginning the study. Considering that $90 \%$ of the recordings could be reproduced within a difference of $0.5 \mathrm{~mm}$, a high reliability was observed (Cronbach's alpha 0,995).

Statistical evaluation

For description of the data, mean values, standard deviations (SD) and frequencies were used. Patients lost to follow-up examinations were censored. All testing was performed by the use of SPSS 22.0 software package (SPSS inc., Chicago, Illinois, USA).

Kolmogorov-Smirnov test was used to determine the distribution of continuous variables. Continuous variables were expressed as means \pm standard deviation and compared at baseline by the U Mann-Whitney test. Mean changes between 6 months (CBCT2) and baseline measurements (CBCT1) were analyzed using Wilcoxon test and mean changes between 6 months (CBCT2) and baseline measurements (CBCT1) between groups were analyzed by $\mathrm{U}$ 
Mann Whitney Test. A Spearman test was used to evaluate correlations between baseline buccal plate width and ridge width and between baseline buccal plate width and buccal plate height at 6 months. Significance was set at alpha $=0.05$ in all tests. 
RESULTS 


\section{RESULTS}

\section{Sample characteristics}

A total of 35 patients were recruited ( 22 women/13 men, mean age: $54 \pm 19.7$ years). Of the 35 inserted implants, 20 belonged to the flapless group and 15 to the flap group. Implant locations and reasons for extraction are detailed in Table 1. All patients completed the study and no complications occurred during any of the surgical procedures or during the 6-months follow-up.

\begin{tabular}{|c|c|c|}
\hline Treatment group & Tooth Number & Reason for extraction \\
\hline Flap Group & 42 & Non restorable \\
\hline Flap Group & 24 & Non restorable \\
\hline Flap Group & 14 & Non restorable \\
\hline Flap Group & 21 & Trauma \\
\hline Flap Group & 25 & Non restorable \\
\hline Flap Group & 44 & Non restorable \\
\hline Flap Group & 21 & Non restorable \\
\hline Flap Group & 45 & Non restorable \\
\hline Flap Group & 24 & Non restorable \\
\hline Flap Group & 15 & Non restorable \\
\hline Flap Group & 11 & Non restorable \\
\hline Flap Group & 31 & Non restorable \\
\hline Flap Group & 21 & Non restorable \\
\hline Flap Group & 14 & Non restorable \\
\hline Flap Group & 25 & Non restorable \\
\hline Flapless Group & 14 & Non restorable \\
\hline Flapless Group & 24 & Non restorable \\
\hline Flapless Group & 11 & Non restorable \\
\hline Flapless Group & 23 & Non restorable \\
\hline
\end{tabular}




\begin{tabular}{|l|l|l|}
\hline Flapless Group & 21 & Trauma \\
\hline Flapless Group & 12 & Non restorable \\
\hline Flapless Group & 21 & Non restorable \\
\hline Flapless Group & 12 & Non restorable \\
\hline Flapless Group & 12 & Trauma \\
\hline Flapless Group & 21 & Non restorable \\
\hline Flapless Group & 22 & Non restorable \\
\hline Flapless Group & 22 & Non restorable \\
\hline Flapless Group & 21 & Non restorable \\
\hline Flapless Group & 33 & Non restorable \\
\hline Flapless Group & 44 & Non restorable \\
\hline Flapless Group & 14 & Non restorable \\
\hline Flapless Group & 25 & Non restorable \\
\hline Flapless Group & 14 & Non restorable \\
\hline Flapless Group & 15 & 21 \\
\hline Flapless Group & & \\
\hline
\end{tabular}

Table 1. Tooth type and reason for extraction in both treatment groups. 


\section{General analysis}

During the entire observation period, a statistically significant reduction in buccal and lingual alveolar bone height, as well as in ridge width was seen. The differences between baseline and 6 months in buccal plate height, lingual plate height and in ridge width at 2, 4 and $6 \mathrm{~mm}$ were 0.48 $\pm 1.35 ; 0.58 \pm 1.51 ; 0.64 \pm 0.81 ; 0.59 \pm 1.36$ and $0.52 \pm 1.16$ respectively.

\begin{tabular}{|l|l|l|l|}
\hline Variables & $\begin{array}{l}\text { Baseline (CBCT1) } \\
\text { mean (SD) }\end{array}$ & $\begin{array}{l}6 \text { months (CBCT2) } \\
\text { mean (SD) }\end{array}$ & P value ${ }^{1}$ \\
\hline Buccal plate width 1 mm & $1.205(1.0)$ & & ---- \\
\hline Buccal plate width 3 mm & $1.26((0.81)$ & & ---- \\
\hline $\begin{array}{l}\text { Buccal plate width } 5 \mathrm{~mm} \\
(\mathrm{n}=32)\end{array}$ & $1.095(0.77)$ & & ---- \\
\hline Buccal height & $19.5(4.7)$ & $19.0(4,2)$ & $0.045^{*}$ \\
\hline Lingual height & $17.9(2.9)$ & $17.3(3,2)$ & $0.036^{*}$ \\
\hline Ridge width 2 mm (n=31) & $9.2(1.8)$ & $8.4(1,6)$ & $0.001^{*}$ \\
\hline Ridge width 4 mm (n=34) & $9.6(2.0)$ & $9.0(1,7)$ & $0.005^{*}$ \\
\hline Ridge width 6 mm (n=34) & $10.0(2.3)$ & $9.4(2)$ & $0.008^{*}$ \\
\hline
\end{tabular}

1 Wilcoxon test for paired samples.

* Statistical significance

Table 2. Mean height and width values at baseline and 6 months. 


\section{Baseline buccal bone thickness and bone volume alterations}

When analyzing the influence of the initial buccal plate thickness on volume changes at 6 months, a moderate positive linear relationship (rho: $0.561, \mathrm{p}=0.001$ ) was observed between baseline buccal plate width at $1 \mathrm{~mm}$ and a reduction in buccal plate height. However, no correlation was observed between baseline buccal plate width at $3 \mathrm{~mm}$ and $5 \mathrm{~mm}$ and ridge width at 6 months (Table 3).

\begin{tabular}{|c|c|c|c|c|c|}
\hline & & & $\begin{array}{l}\text { Difference ridge } \\
\text { width } 2 \mathrm{~mm} \\
(6 \text { months }) \\
\end{array}$ & $\begin{array}{l}\text { Difference in } \\
\text { ridge width } 4 \mathrm{~mm} \\
(6 \text { months })\end{array}$ & $\begin{array}{l}\text { Difference in } \\
\text { ridge width } 6 \mathrm{~mm} \\
(6 \text { months })\end{array}$ \\
\hline \multirow{3}{*}{\multicolumn{2}{|c|}{$\begin{array}{l}\text { Rho Baseline } \\
\text { Spearmanbuccal plate width } 1\end{array}$}} & $\begin{array}{l}\text { Correlation } \\
\text { coeficient }\end{array}$ & .110 & .203 & .561 \\
\hline & & Sig. (bilateral) & .586 & .250 & $.001^{*}$ \\
\hline & & $\mathrm{N}$ & 27 & 34 & 34 \\
\hline \multirow{3}{*}{\multicolumn{2}{|c|}{$\begin{array}{l}\text { Baseline } \\
\text { buccal plate width } 3\end{array}$}} & $\begin{array}{l}\text { Correlation } \\
\text { coeficient }\end{array}$ & .238 & .058 & .246 \\
\hline & & Sig. (bilateral) & .232 & .743 & .160 \\
\hline & & $\mathrm{N}$ & 27 & 34 & 34 \\
\hline \multirow{3}{*}{\multicolumn{2}{|c|}{$\begin{array}{l}\text { Baseline } \\
\text { buccal plate width } 5\end{array}$}} & $\begin{array}{l}\text { Correlation } \\
\text { coeficient }\end{array}$ & .000 & .044 & .046 \\
\hline & & Sig. (bilateral) & .998 & .815 & .803 \\
\hline & & $\mathrm{N}$ & 24 & 31 & 32 \\
\hline
\end{tabular}

* Statistical significance

Table 3. Correlations between baseline buccal plate width at $1 \mathrm{~mm}, 3 \mathrm{~mm}$ and $5 \mathrm{~mm}$ and ridge width at $2 \mathrm{~mm}, 4$ $\mathrm{mm}$ and $6 \mathrm{~mm}$ at 6 months. 


\section{Flap versus flapless approach}

No statistically significant differences were found between groups at baseline. Table 4 shows the mean dimensions at baseline and at 6 months in both treatment groups. In the control group, a mean difference of $1.03(\mathrm{p}=0.006)$ in vestibular height was observed while the ridge width decreased $0.84 \mathrm{~mm}(\mathrm{p}=0.003), 1.09 \mathrm{~mm}(\mathrm{p}=0.005)$ and $0.91 \mathrm{~mm}(\mathrm{p}=0,024)$ at 2,4 and $6 \mathrm{~mm}$ respectively. In the flapless group on the other hand, the only statistically significant bone dimension changes between the two observation time points were detected for lingual plate height (mean decrease of $0.91 \mathrm{~mm}$; $=0.018$ ) and ridge width at $2 \mathrm{~mm}$ (mean decrease of $0.48 \mathrm{~mm} ; \mathrm{p}=0.028$ ). The differences from baseline to 6 months in ridge height and width between treatment groups did not reach statistical significance (Table 5). However, in the control group ridge width decreased $9.07 \pm 8.52 \%$ at $2 \mathrm{~mm}, 9.09 \pm 11.61 \%$ at $4 \mathrm{~mm}$ and $7.22 \pm 9.51 \%$ at $6 \mathrm{~mm}$ while in the treatment group ridge width a smaller shrinkage was observed $(5.44 \pm 9.88 \%$, $2.02 \pm 9.57 \%$ and $2.89 \pm 10.99 \%$ at 2,4 and $6 \mathrm{~mm}$ respectively). 


\begin{tabular}{|c|c|c|c|c|c|c|c|}
\hline & Baseline & & & 6 months & & \\
\hline $\begin{array}{c}\text { Mean (SD) } \\
\mathrm{N}=15\end{array}$ & $\begin{array}{c}\text { Flapless } \\
\text { Mean (SD) } \\
\mathrm{N}=20\end{array}$ & $\begin{array}{c}\mathrm{P} \\
\text { value }\end{array}$ & $\begin{array}{c}\text { Flap } \\
\text { Mean (SD) } \\
\mathrm{N}=15\end{array}$ & $\begin{array}{c}\mathrm{P} \\
\text { value }^{2}\end{array}$ & $\begin{array}{c}\text { Flapless } \\
\text { Mean (SD) } \\
\mathrm{N}=20\end{array}$ & P value $^{3}$ \\
\hline $\begin{array}{c}\text { Buccal plate } \\
\text { width1 mm }\end{array}$ & $1.15(0.6)$ & $1.24(0.9)$ & 0.458 & & & & \\
\hline $\begin{array}{c}\text { Buccal plate } \\
\text { width 3 mm }\end{array}$ & $1.35(0.6)$ & $1.19(0.9)$ & 0.635 & & & & \\
\hline $\begin{array}{c}\text { Buccal plate } \\
\text { width 5 mm } \\
\text { (N=32) }\end{array}$ & $1.35(0,9)$ & $0.89(0.6)$ & 0.156 & & & & \\
\hline Buccal height & $21.12(4.8)$ & $18.34(4.5)$ & 0.080 & $20.09(4.4)$ & 0.006 & $18.26(4.0)$ & 0.841 \\
\hline Lingual height & $17.25(3.3)$ & $18.33(2.7)$ & 0.730 & $17.10(3.6)$ & 0.691 & $17.41(2.9)$ & 0.018 \\
\hline $\begin{array}{c}\text { Ridge width 2 } \\
\text { mm (N=31) }\end{array}$ & $9.88(1,8)$ & $8.66(1.7)$ & 0.059 & $8.51(1,3)$ & 0.003 & $8.35(1.8)$ & 0.028 \\
\hline $\begin{array}{c}\text { Ridge width 4 } \\
\text { mm (n=34) }\end{array}$ & $10.21(2.1)$ & $9.05(1.9)$ & 0.104 & $9.11(1.3)$ & 0.005 & $8.85(1.9)$ & 0.205 \\
\hline $\begin{array}{c}\text { Ridge width 6 } \\
\text { mm (N=34) }\end{array}$ & $10.74(2.6)$ & $9.42(1.26)$ & 0.138 & $9.80(1.7)$ & 0.024 & $9.17(2.3)$ & 0.198 \\
\hline
\end{tabular}

${ }^{1}$ U Mann Whitney test $;{ }^{2}$ Wilcoxon test (related analysis in flap group); ${ }^{3}$ Wilcoxon test (related analysis in flapless group)

Table 4. Baseline and 6 months comparisons in flap and flapless groups. 


\begin{tabular}{|c|c|c|c|c|c|}
\hline & GROUP & $\mathrm{N}$ & Mean & Standard Deviation & Median(IQR) \\
\hline $\begin{array}{l}\text { Difference } \\
\text { Buccal height } \\
\mathrm{P}=0.056\end{array}$ & $\begin{array}{l}\text { Flap } \\
\text { Flapless }\end{array}$ & $\begin{array}{l}15 \\
20\end{array}$ & $\begin{array}{l}1.0327 \\
0.0725\end{array}$ & $\begin{array}{l}1.09406 \\
1.41799 \\
\end{array}$ & $\begin{array}{l}1,27(-0.05 \text { to } 1.7) \\
-0.035(-0.53 \text { to } 0.86)\end{array}$ \\
\hline $\begin{array}{l}\text { Difference } \\
\text { Lingual height } \\
\mathrm{P}=0.227\end{array}$ & $\begin{array}{l}\text { Flap } \\
\text { Flapless }\end{array}$ & $\begin{array}{l}15 \\
20 \\
\end{array}$ & $\begin{array}{l}0.1433 \\
0.9155 \\
\end{array}$ & $\begin{array}{l}1.64975 \\
1.35254\end{array}$ & $\begin{array}{l}0.54(-1.27 \text { to } 1.36) \\
0.86(-0.075 \text { to } 1.67)\end{array}$ \\
\hline $\begin{array}{l}\text { Difference } \\
\text { Ridge width } 2 \mathrm{~mm} \\
\mathrm{P}=0.456\end{array}$ & $\begin{array}{l}\text { Flap } \\
\text { Flapless } \\
\end{array}$ & $\begin{array}{l}12 \\
15 \\
\end{array}$ & $\begin{array}{l}0.8483 \\
0.4873 \\
\end{array}$ & $\begin{array}{l}0.86311 \\
0.76537 \\
\end{array}$ & $\begin{array}{l}0.59(0.27 \text { to } 1.23) \\
0.59(0 \text { to } 0.98)\end{array}$ \\
\hline $\begin{array}{l}\text { Difference } \\
\text { Ridge width } 4 \mathrm{~mm} \\
\mathrm{P}=0.0 \$ 1\end{array}$ & $\begin{array}{l}\text { Flap } \\
\text { Flapless }\end{array}$ & 19 & $\begin{array}{l}1.0980 \\
0.1968\end{array}$ & $\begin{array}{l}1.72325 \\
0.84655\end{array}$ & $\begin{array}{l}0.78(0.15 \text { to } 1.12) \\
0.18(-0.26 \text { to } 0.77)\end{array}$ \\
\hline $\begin{array}{l}\text { Difference } \\
\text { Ridge width } 6 \mathrm{~mm} \\
\mathrm{P}=0.377\end{array}$ & $\begin{array}{l}\text { Flap } \\
\text { Flapless }\end{array}$ & $\begin{array}{l}14 \\
20\end{array}$ & $\begin{array}{l}0.9136 \\
0.2445\end{array}$ & $\begin{array}{l}1.40860 \\
0.90529\end{array}$ & $\begin{array}{l}0.36(-0.095 \text { to } 1.12) \\
0.34(-0,42 \text { to } 0.74)\end{array}$ \\
\hline $\begin{array}{l}\text { Difference in reduction in } \\
\text { ridge width } 2 \mathrm{~mm}(\%) \\
\mathrm{P}=0.548\end{array}$ & $\begin{array}{l}\text { Flap } \\
\text { Flapless }\end{array}$ & $\begin{array}{l}12 \\
15\end{array}$ & $\begin{array}{l}9,07 \% \\
5,44 \%\end{array}$ & $\begin{array}{l}8,52 \% \\
9,88 \%\end{array}$ & \\
\hline $\begin{array}{l}\text { Difference reduction in ridg } \\
\text { width } 4 \mathrm{~mm}(\%) \\
\mathrm{P}=0.071\end{array}$ & $\begin{array}{l}\text { Elap } \\
\text { Flapless }\end{array}$ & $\begin{array}{l}15 \\
19\end{array}$ & $\begin{array}{l}9,09 \% \\
2,02 \%\end{array}$ & $\begin{array}{l}11,61 \% \\
9,57 \%\end{array}$ & \\
\hline $\begin{array}{l}\text { Difference in reduction in } \\
\text { ridge width } 6 \mathrm{~mm}(\%) \\
\mathrm{P}=0,416\end{array}$ & $\begin{array}{l}\text { Flap } \\
\text { Flapless }\end{array}$ & $\begin{array}{l}14 \\
20\end{array}$ & $\begin{array}{l}7,22 \% \\
2,89 \%\end{array}$ & $\begin{array}{l}9,51 \% \\
10,99 \%\end{array}$ & \\
\hline
\end{tabular}

IQR: Interquartile range

Table 5. Mean changes between baseline and 6 months in both treatment groups. 
DISCUSSION 


\section{DISCUSSION}

Maintenance of the original ridge contour in the anterior maxilla represents a challenge in daily practice (Hämmerle et al. 2012). Ridge preservation procedures, originally intended to maintain bone volume after tooth extraction, have also shown some reduction in height and width (Vignoletti et al. 2012). Jung et al. (2013) using CBCTs showed a mean horizontal reduction of $0.6 \mathrm{~mm}$ and a vertical reduction from 0.0 to $1.2 \mathrm{~mm}$ at extraction sites filled with anorganic bovine bone with no flap elevation at 6 months of healing. Similarly, the results of this investigation show that immediate implant placement with simultaneous bone grafting does not entirely avoid bone resorption. Thus, a mean reduction of around $0.5 \mathrm{~mm}$ in height and width were observed. Although immediate implant placement may lead to a similar reduction in width as ridge preservation, it limits the number of surgical interventions and chair-time, increasing thereby patients' satisfaction.

\section{Hard tissue alterations}

Our findings are in accordance with the outcomes presented in a recent meta-analysis, where a mean vertical reduction of $0.78 \mathrm{~mm}$ in the buccal wall and $0.50 \mathrm{~mm}$ on the lingual plate were reported. Mean width reduction was $1.07 \mathrm{~mm}$ and 0.62 on the buccal and lingual aspects respectively (Lee et al. 2014).

Table 6 summarizes the methodology and results of other studies that have evaluated hard dimensional changes after type I implant placement and simultaneous bone grafting. Our results agree with what has been previously reported in the literature. The outcomes on horizontal 
reduction range from 0.31 to $1.23 \mathrm{~mm}$, while we found $0.64 \pm 0.81 \mathrm{~mm} 2 \mathrm{~mm}$ apically from the buccal crest. In our study we found a vertical resorption of $0.48 \pm 1.35 \mathrm{~mm}$ on the buccal crest, which is in the range of other studies $(0.1-1 \mathrm{~mm})$. The two retrospective studies with a follow up of 3 (Cosyn et al. 2013) and 7 years (Benic et al. 2012) show a bone reduction of around 1mm. It can be suggested that, although most dimensional changes occur within the first 6 months of healing, small alterations may still take place after this period.

The majority of investigations have filled the gap with demineralized bovine bone mineral (DBBM) at time of implant placement. DBBM particles have shown to have a slow resorption rate which make them suitable to maintain an adequate bone volume over time (Araújo et al. 2009). An experimental study on beagle dogs compared hard tissue alterations after immediate implant placement with or without grafting the gap with DBBM. After 6 months of healing, it was observed that the buccal bone crest was located much closer to the implant shoulder and was comparatively much thicker at grafted sites versus control sites. This resulted in $1 \mathrm{~mm}$ apical migration of the soft tissue margin at non-grafted implants with respect to the experimental group. The authors concluded that DBBM minimized the hard tissue remodeling process and therefore prevented soft tissue recession (Araújo et al. 2011). 


\begin{tabular}{|c|c|c|c|c|c|c|c|c|}
\hline AUTHOR/YEAR & $\begin{array}{l}\text { STUDY } \\
\text { DESIGN }\end{array}$ & $\begin{array}{c}\text { FOLLOW } \\
\text { UP }\end{array}$ & SAMPLE & SURGERY & GRAFT & METHOD & $\begin{array}{l}\text { H CHANGE } \\
(\mathrm{mm})\end{array}$ & $\begin{array}{l}\text { V CHANGE } \\
(\mathrm{mm})\end{array}$ \\
\hline Degidi et al. 2012 & Prosp. & $12 \mathrm{~m}$ & 69 & Flapless & DBBM & CBCT & $0.88 \pm 0.51$ & $0.76 \pm 0.96$ \\
\hline Roe et al. 2012 & Prosp. & $12 \mathrm{~m}$ & 21 & Flapless & DBBM & CBCT & $1.23 \pm 0.75$ & $0.82 \pm 0.64$ \\
\hline Chen et al. 2007 & RCT & $6 \mathrm{~m}$ & 30 & Flap & DBBM & Re-entry & $0.4 \pm 0.50$ & $0.1 \pm 3.4$ \\
\hline Gher et al. 1994 & Prosp. & $6 \mathrm{~m}$ & 10 & Flap & DFDBA & Re-entry & - & $0.90 \pm 1.70$ \\
\hline Assaf et al. 2013 & Prosp. & $6 \mathrm{~m}$ & 11 & Flapless & $\mathrm{BCP}$ & CBCT & $-0.16 \pm 1.0$ & - \\
\hline Benic et al. 2012 & Prosp. & $7 y$ & 14 & Flap & DBBM & CBCT & $1.7 \pm 0.6$ & $0.6 \pm 0.8$ \\
\hline $\begin{array}{c}\text { Morimoto et al. } \\
2014 \\
\end{array}$ & Retrosp. & $12-15 \mathrm{~m}$ & 12 & Flapless & $\begin{array}{c}\text { Not } \\
\text { specified }\end{array}$ & CBCT & $0.31 \pm 0.23$ & $0.25 \pm 0.1$ \\
\hline Cosyn et al. 2013 & Prosp. & $3 y$ & 25 & Flap & DBBM & $\begin{array}{c}\text { Periapical } \\
\text { rx } \\
\end{array}$ & - & 1.00 \\
\hline Covani et al. 2014 & Prosp. & $5 y$ & 47 & Flapless & DBBM & $\begin{array}{c}\text { Periapical } \\
\text { rx } \\
\end{array}$ & - & $1.08 \pm 0.43$ \\
\hline $\begin{array}{c}\text { De Rouck et al. } \\
2009\end{array}$ & $\mathrm{RCT}$ & $12 \mathrm{~m}$ & 49 & Flap & DBBM & $\begin{array}{l}\text { Periapical } \\
\text { rx }\end{array}$ & - & $0.96 \pm 025$ \\
\hline $\begin{array}{c}\text { Valentini et al. } \\
2010 \\
\end{array}$ & Prosp. & $12 \mathrm{~m}$ & 40 & Flap & DBBM & $\begin{array}{c}\text { Periapical } \\
\text { rx } \\
\end{array}$ & - & $0.30 \pm 0.81$ \\
\hline Present study & Prosp & $6 \mathrm{~m}$ & 35 & $\begin{array}{c}\text { Flap } \\
\text { Flapless }\end{array}$ & DBBM & CBCT & $0.64 \pm 0.81$ & $0.48 \pm 1.35$ \\
\hline
\end{tabular}

- : not reported; Prosp: prospective study; Retrosp: retrospective study; DBBM: Demineralized bovine bone mineral; BCP: Beta tricalcium phosphate; rx: radiographs

Table 6: Studies that have combined immediate implant placement and bone augmentation techniques. 


\section{Flap versus flapless approach}

When comparing bone volume changes between flap and flapless groups, no statistical significant differences were found between groups. However, the gathered data on CBCTs might be clinically relevant. Hence, in the flap group, the buccal plate height decreased $1.03 \mathrm{~mm}$ and ridge width $0.84 \mathrm{~mm}$ at $2 \mathrm{~mm}$. Meanwhile, in the flapless group, the buccal height remained almost stable $(0.08 \mathrm{~mm}$ difference $)$ and the reduction in ridge width ranged from 0.2 to $0.31 \mathrm{~mm}$.

Three other studies have evaluated hard tissue changes after flapless immediate implant placement and simultaneous bone grafting (Degidi et al. 2012; Roe et al. 2012; Morimoto et al. 2014). Morimoto et al. (2014) observed a mean vertical and horizontal reduction of the buccal wall of $0.31 \pm 0.23 \mathrm{~mm}$ and $0.25 \pm 0.1 \mathrm{~mm}$ respectively, which is in accordance to our findings. However, Roe et al. (2012) and Degidi et al. (2012) observed a reduction of around 0.8mm in height and width at 12 months of healing.

At the lingual crest, a difference of 0.15 and $0.92 \mathrm{~mm}$ in height was observed in the control and treatment groups respectively. A more palatal placement of the implants in the flapless group could explain the increased lingual height reduction as well as the greater stability of the buccal wall height in this treatment group (Tomasi et al. 2010).

Blanco et al. (2008) compared flap and flapless approach on immediate implants in a beagle dog model and showed that, at three months, the first bone to implant contact was located more apically on those sites were a flap had been raised, but it was not statistically significant. On the contrary, some other studies have found no significant differences in bone level changes between the two surgical protocols. Caneva et al. (2010) observed comparable buccal bone dimensions in both groups in an animal study at 4 months. 
To our knowledge, this is the first human observational study analyzing the influence of raising a flap on bone volume changes after immediate implant placement. Table 6 shows the bone alterations in height and width of studies that have performed a flap or a flapless approach. However, the results seem to be heterogeneous and do not allow us to confirm whether a flapless approach improves ridge contour maintenance. Results of a recent regression analysis showed a direct relationship between raising a flap and a bone level change of $>0.5 \mathrm{~mm}$ (Slagter et al. 2014).

Influence of buccal bone plate thickness

The alveolar bone surrounds the teeth and transmits the forces of occlusion through the periodontal ligament. The portion of the bone in which the periodontal ligament is attached is known as bundle bone. The crestal portion of the buccal and lingual bone plates is mostly comprised by cortical bundle bone (Araújo et al. 2005). Once a tooth is removed, bundle bone resorbs due to the lack of vascular supply and function and a reduction in height and width of the buccal plate takes place.

The Spearmen test showed a moderate positive correlation between the initial buccal bone plate thickness $1 \mathrm{~mm}$ below the crest and a buccal bone height at 6 months. Thus, the thinner the buccal plate, the more reduction in height was seen. Ferrus at al. (2010) observed that, when the buccal bone crest was thicker than $1 \mathrm{~mm}$, there was a smaller decrease in the buccal bone height at 4 months post-extraction. Likewise, Lee et al. (2014) performed a meta-regression analysis of studies evaluating dimensional changes after immediate implant placement in which the buccal 
plate thickness ranged from $0.4-1.4 \mathrm{~mm}$ and observed that thick buccal plates were associated with less vertical reduction.

In the present study, the mean baseline buccal plate width was around $1.1 \mathrm{~mm}$ wide and anorganic bovine bone was placed to fill the buccal residual gap, which may explain the lack of correlation with buccal bone width at 6 months. Huynh-Ba (2010) also observed a mean buccal bone thickness of $1 \mathrm{~mm}$ but highlighted that in $71 \%$ of the cases it was between $0,5-1 \mathrm{~mm}$. Furthermore, Januário et al. (2011) registered a mean buccal bone thickness of $0.5-0,6 \mathrm{~mm}$ in maxillary incisors and canines $5 \mathrm{~mm}$ apical to the crest on CBCTs. If that had been the case in the present study, a more pronounced reduction in buccal height and width could have been observed (Ferrus, 2010). However, a meta-regression analysis observed that thicker buccal plates were related to more horizontal bone loss during healing. However, the authors highlighted that extremely thin buccal plates can still lead to a more pronounced buccal horizontal resorption (Lee et al. 2014).

\section{Soft tissue changes}

The presence of an adequate bone housing around implants has been reported to assure soft tissue stability in the long term (Grunder et al. 2005). A recent systematic review tried to determine the minimum amount of buccal bone width needed to avoid an apical displacement of the soft tissues over time but they could not define a threshold due to lack of evidence (Teughels et al. 2009). 
It has been observed that soft tissue alterations occur during the first 4 months of healing and, after that period, soft tissue levels remain almost stable (Ramaglia et al. 2015).

The main aesthetic complication around immediate plants is the presence of an advanced recession (Chen \& Buser, 2009). This study evaluated bone dimensions around immediate implants on CBCTs but no information of the soft tissues was reported.

In this sense, Raes et al. (2011) assessed the hard and soft tissue response after placing immediate implants with no additional bone grafting. At one year, a $0.85 \mathrm{~mm}$ mean vertical bone loss and a mean $0.12 \pm 0.78 \mathrm{~mm}$ of midfacial recession. Only $7 \%$ of the cases showed a recession of more than $1 \mathrm{~mm}$. When comparing soft tissue levels of type I implants placed in a flap or a flapless approach, a mean difference of $0.89 \mathrm{~mm}$ in midfacial recession between the two protocols was observed.

Another investigation on immediate implants with simultaneous bone augmentation evaluated osseous and mucosal tissue changes at one year. The mean vertical bone loss measured on standardized periapical radiographs was $0.96 \pm 0.25 \mathrm{~mm}$ and $0.97 \pm 0.35 \mathrm{~mm}$ mesially and distally which led to a mean reduction of $0.43 \pm 0.42 \mathrm{~mm}$ and $0.53 \pm 0.55 \mathrm{~mm}$ of the mesial and distal papilla respectively, They reported a mean midfacial recession of $1.16 \pm 0.66 \mathrm{~mm}$ (De Rouck et al. 2009). 


\section{Methodology}

When analysing bone dimensional changes three methods have been employed: clinical intrasurgical measurements by means of a re-entry procedure (Gher et al. 1994; Boticelli et al. 2004, 2008; Chen et al. 2007; Ferrus et al. 2010) or radiographic measurements on CBCTs (Roe et al. 2012; Benic et al. 2012; Degidi et al. 2012; Assaf et al. 2013; Morimoto et al. 2015) or periapical radiographs (De Rouck et al. 2009; Valentini et al. 2010; Cosyn et al. 2013; Covani et al. 2014).

Re-entry measurements have been considered the gold standard but it not only implies an additional surgery and harm to our patients, but may also contribute to additional bone resorption. When a mucoperiosteal flap is raised, the periosteun is separated from the alveolar bone, which induces osteoclastic activity on the outer osseous surfaces (Fickl et al. 2011). After full-thickness flap elevation, a bone loss of $0.6 \mathrm{~mm}$ has been reported (Donnenfeld et al. 1964).

The use of periapical radiographs only gives us information about the interproximal bone level changes, while midfacial recession is mainly associated buccal bone dimensions. Therefore, it may be not a suitable method to predict aesthetic complications in the future. Moreover, measurements taken on this radiographs should be considered cautiously since the image always has some degree of distorsion even if they are taken in a standardized way. A study comparing measurements taken on periapical radiographs and direct measurements in cadavers with a caliper showed statistically significant differences between the two methodologies (Takeshita et al. 2014). 
CBCTs have clearly transformed diagnosis and treatment plans in all fields of dentistry. A study comparing intrasurgical measurements on teeth with those obtained on CBCTs have shown a high degree of accuracy (Takeshita et al. 2014).

However, metal objects such as implants, may lead to artifacts which may difficult the assessment of the surrounding bone dimensions (Razavi et al. 2010, Schultze et al. 2010; Benic et al. 2012). A recent preclinical study compared direct measurements taken on implants placed in bovine ribs with measurements taken on CBCTs. Several examiners measured the vertical distance from the implant shoulder to the first bone-to-implant contact and the buccal bone thickness at 3,6, and 9mm below the buccal bone crest. In general, a greater vertical distance and less buccal bone thickness was measured on CBCTs. Horizontal measurements were more accurate 6 and $9 \mathrm{~mm}$ below the alveolar crest than at $3 \mathrm{~mm}$, presumably due to an increased thickness of the buccal wall. All the examiners referred difficulties in localizing the boneimplant interface (Razavi et al. 2010). On the other hand, Shiratori et al. (2012) compared buccal bone measurements at different levels on skulls and CBCTs and observed no significant differences between the two methods.

\section{Limitations}

Biases are any factors or processes that deviate the results or conclusions of the study away from the truth. The best way to minimize the risk of bias is by conducting double blind randomized clinical trials. This way, every subject has the same probability to be in any treatment group and neither the researcher nor the patient knows the treatment group assignment. Randmozed 
clinical trials are therefore considered the best proof to estimate the efficacy of a therapy (Montenegro et al. 2002; Nieri et al. 2007; Cairo et al. 2012).

The present study was a non-randomized observational study. Subjects were allocated into groups following the surgeon's choice to raise a flap or not at time of tooth extraction. Anatomical features such as the gingival biotype or the buccal plate thickness could have influenced the surgical protocol and therefore patient assignment resulting in an increased risk of bias. However, it has to be pointed out that the researcher that performed the radiographic analysis on CBCTs was blinded to the treatment group.

The lack of statistically significant differences between groups may have been due to a small sample size. When sample size calculation was performed, a difference of $1.2 \mathrm{~mm}$ of ridge width difference between groups was considered to have a P-value $<0.05$. Thus, although the differences between groups were in clinically significant, they did not reach statistical significance.

To sum up, based on the results of this prospective observational study, we may reject the following null hypotheses $\left(\mathrm{H}_{0}\right)$ :

$\mathbf{H}_{\mathbf{0}}$ : Flap elevation will not result in a greater reduction in height and width of the alveolar ridge at 6 months healing.

$\mathbf{H}_{\mathbf{0}}$ : Initial buccal bone width will not be related to ridge dimensions at 6 months of healing. 
CONCLUSIONS 


\section{CONCLUSIONS}

In conclusion, according to the aims of the present study, we may assume that:

- A mean reduction of around $0,5 \mathrm{~mm}$ in height and width after placing immediate implants and filling the residual gap with anorganic bovine bone might be expected.

- No statistically significant differences in outcomes were found between the flap and the flapless group, although more ridge reduction was observed for the flap group.

- Initial buccal bone width was positively correlated with buccal bone height at six months, but no significant correlation with ridge width at 6 months was seen. 
FUTURE PERSPECTIVES 


\section{FUTURE PERSPECTIVES}

Immediate implant placement with simultaneous bone grafting in a flapless approach seems to be efficient in terms of minimizing hard tissue alterations.

Since randomized clinical trials are considered to provide the greatest level of evidence, it would be interesting to perform a well-designed randomized clinical trial comparing the following treatment approaches:

- Immediate implant placement with flap elevation.

○ Flapless immediate implant placement.

- Immediate implant placement with simultaneous bone grafting and flap elevation

- Flapless immediate implant placement with simultaneous bone grafting.

Additionally, not only hard tissue measurements on CBCTs should be considered, but also the clinical assessment soft tissue stability over time, as midfacial recession is the main aesthetic complication that may appear.

Last but not least, other strategies such as the placement of a connective tissue graft or immediate provisionalization on type I implants should be evaluated since the preliminary results seem to be promising. 
REFERENCES 


\section{REFERENCES}

Araújo, M.G., Sukekava F., Wennström, J.L. \& Lindhe, J. (2005) Ridge alterations following implant placement in fresh extraction sockets: an experimental study in the dog. Journal of Clinical Periodontology 32: 645-652.

Araújo, M. G., Wennström, J.L. \& Lindhe J. (2006) Modelling of the buccal and lingual bone walls of fresh extraction sites following implant installation. Clinical Oral Implants Research 17: $606-614$.

Araújo, M.G. \& Lindhe, J. (2009) Ridge Preservation with the use of Bio-Oss ${ }^{\circledR}$ collagen: a 6month study in the dog. Clinical Oral Implants Research 20: 433-440.

Araújo, M.G., Linder, E. \& Lindhe, J. (2011) Bio-Oss ${ }^{\circledR}$ Collagen in the buccal gap at immediate implants: a 6-month study in the dog. Clinical Oral Implants Research 22: 1-8.

Assaf, J.H., Zanatta, F.B., Barbosa de Brito, R. \& Franca, F.M.G. (2013) Computed tomographic evaluation of alterations of the buccolingual width of the alveolar ridge after immediate implant placement associated with the use of a synthetic bone substitue. The International Journal of Oral Maxillofacial \& Implants 28: 757-763.

Atieh, M.A., Payne, A.G.T., Duncan, W.J. \& Cullinan, M.P. (2009) Immedaite restoration/loading of immediately placed single implants: is it an effective bimodal approach? Clinical Oral Implants Research 20: 645-659. 
Becker, W., Becker, B.E., Polizzi, G. \& Bergstrom, C. (1994) Autogenous bone grafting of defects adjacent to implants placed into immediate extraction sockets in patients: A prospective study. The International Journal of Oral Maxillofacial \& Implants 9: 389-96.

Becker, W., Dahlin, C., Becker, B.E., Lekholm, U., van Steenberghe, D., Higuchi, K. \& Kultje, C. (1994) The use of e-PTFE barrier membranes for bone promotion around titanium implants placed into extraction sockets: a prospective multicenter study. The International Journal of Oral Maxillofacial \& Implants 9: 31-40.

Benic, G.I., Mokti, M., Chen, C.J., Weber, H.P., Hämmerle, C.H.F. \& Galucci, G.O. (2012) Dimensions of buccal bone and mucosa at immediately placed implants after 7 years: a clinical and cone beam computer tomography study. Clinical Oral Implants Research 23: 560-566.

Bianchi, A.E. \& Sanfilippo, F. (2004) Single-tooth replacement by immediate implant and connective tissue graft: a 1-9 year clinical evaluation. Clinical Oral Implants Research 15: 269277.

Blanco, J., Nuñez, V., Aracil, L., Muñoz, F., Ramos, I. (2008) Ridge alterations following immediate implant placement in the dog: flap versus flapless surgery. Journal of Clinical Periodontology 35: 640-648.

Branemark, P.I., Adell, R., Breine, U., Hansson, B.O., Lindström, J. \& Ohlsson, A. (1969) Intraosseous anchorage of dental prostheses I. Experimental studies. Scandinavian Journal of Plastic Reconstructive Surgery 3: 81-100. 
Braut, V., Bornstein. M., Belser, U. \& Buser, D. (2011) Thickness of the anterior maxillary facial bone wall-A retrospective radiographic study using cone beam computed tomography. The International Journal of Periodontics and Restorative Dentistry 31: 125-131.

Boticelli, D., Berglundh, T. \& Lindhe, J. (2004) Hard-tissue alterations following immediate implant placement in extraction sites. Journal of Clinical Periodontology 31: 820-828.

Boticelli, D., Persson, L., Lindhe, J. \& Berglundh, T. (2006) Bone tissue formation adjacent to implants places in fresh extraction sockets: an experimental study in dogs. Clinical Oral Implants Research 17: 351-358.

Boticelli, D., Renzi, A., Lindhe, J. \& Berglundh, T. (2008) Implants in fresh extraction sockets: a prospective 5-year follow-up clinical study. Clinical Oral Implants Research 19: 1226-1232.

Buser, D., Bornstein, M.M., Weber, H.P., Grütter, L. Schmid, B. \& Belser, U.C. (2008a). Early implant placement with simultaneous guided bone regeneration following single-tooth extraction in the esthetic zone: a cross-sectional, retrospective study in 45 subjects with a 2- to 4-years follow-up. Journal of Periodontology 79: 1773-1781.

Buser, D., Chen, S.T., Weber, H.P. \& Belser, U.C. (2008b) Early implant placement following single-tooth extraction in the esthetic zone: biologic rationale and surgical procedures. The International Journal of Periodontics \& Restorative Dentistry 28: 441-451.

Buser, D., Halbritter, S., Hart, C., Bornstain, M.M., Grutter, L., Chappuis, V. \& Belser, U.C. (2009) Early implant placement with simultaneous guided bone regeneration following single- 
tooth extraction in the esthetic zone: 12-month results of a prospective study with 20 consecutive patients. Journal of Periodontology 80: 152-162.

Buser, D., Wittneben, J., Bornstein, M.M., Grütter, L., Chappuis, V. \& Belser, U.C. (2011) Stability of contour augmentation and esthetic outcomes of implant-supported single crowns in the esthetic zone: 3-year results of a prospective study with early implant placement postextraction. Journal of Periodontology 82: 342-349.

Cairo, F., Sanz, I., Matesanz, P., Nieri, M. \& Pagliaro, U. (2012) Quality of reporting of randomized clinical trials in implant dentistry. A systematic review on critical aspects in design, outcome assessment and clinical relevance. Journal of Clinical Periodontology 39 (Suppl. 12): 81-107.

Caneva, M., Botticelli, D., Salata, L.A., Souza, S.L.S., Bressan, E. \& Lang, N.P. (2010) Flap vs. "flapless" surgical approach at immediate implants: a histomorphometric study in dogs. Clinical Oral Implants Research 21: 1314-1319.

Cangini, F. \& Cornelini, R. (2005) A comparison between enamel matrix derivative and a bioabsorbable membrane to enhance healing around transmucosal immediate post-extraction implants. Journal of Periodontology 76: 1785-92.

Canullo, L. \& Rasperini, G. (2007) Preservation of periimplant soft and hard tissues using platform swithcing of implants placed in immediate extraction sockets: a proof-of-concept study with 12- to 36-month follow-up. The International Journal of Oral Maxillofacial \& Implants 22: 995-1000. 
Carranza, E.A., Itoiz, M.E., Cabrini, R.L. \& Dotto C.A. (1966) A study of periodontal vascularization in different laboratory animals. Journal of Periodontal Research 1: 120-128.

Chen, S.T., Wilson, T.G., Jr \& Hämmerle, C.H. (2004) Immediate or early placement of implants following tooth extraction: review of biologic basis, clinical procedures, and outcomes. The International Journal of Oral Maxillofacial \& Implants 19: 12-25.

Chen, S.T., Darby, I.B. \& Reynolds, E.C. (2007) A prospective clinical study of non-submerged immediate implants: clinical outcomes and esthetic results. Clinical Oral Implants Research 28: $552-562$

Chen, S.T. \& Buser, D. (2014) Esthetic outcomes following immediate and early implant placement in the anterior maxilla - a systematic review. The International Journal of Oral \& Maxillofacial Implants 29 (Suppl): 186-215.

Clementini, M., Tiravia, L., De Risi, V., Vittorini Orgeas G., Mannocci, A. \& de Sanctis, M. (2015) Dimensional changes after immediate implant placement with or without simultaneous regenerative procedures: a systematic reviw and meta-analysis. Journal of Clinical Periodontology 42: 666-677.

Corbella, S., Taschieri, S., Tsesis, I. \& Del Fabbro, M. (2013) Postextraction implant in sites with endodontic infection as an alternative to endodontic retreatment: a review of literature. Journal of Oral Implantology 39: 399-405. 
Cordaro, T., Torsello, F. \& Rocuzzo, M. (2009) Clinical outcomes of submerged vs. nonsubmerged implants placed in fresh extraction sockets. Clinical Oral Implants Research 20: 1307-1313.

Cosyn, J. \& De Rouck, T. (2009). Aesthetic outcome of single-tooth implant restorations following early implant placement and guided bone regeneration: crown and soft tissue dimensions compared with contralateral teeth. Clinical Oral Implants Research 20: 1063-1069.

Cosyn, J., Eghbali, A., De Bruyn, H., Clloys, K., Cleymaet, R. \& De Rouck, T. (2011) Immediate single-tooth implants in the anterior maxilla: 3-year results of a case series on hard and soft tissue response and aesthetics. Journal of Clinical Periodontology 38: 746-753.

Cosyn, J., Eghbali, A., Hansealer, L., De Rouck, T., Wyn, I., Sabzebar, M.M., Claymaet R. \& De Bruyn, H. (2013) Four modalities of single implant treatment in the anterior maxilla: a clinical, radiographic and aesthetic evaluation. Clinical Implant Dentistry and Related Research 15: $517-$ 530.

Cosyn, J., Hooghe, N. \& De Bruyn, H. (2012) A systematic review on the frequency of advanced recession following single immediate implant treatment. Journal of Clinical Periodontology 39: $582-589$

Covani, U., Cornelini, R. \& Barone A. (2007) Vertical crestal bone changes around implants placed into fresh extraction sockets. Journal of Periodontology 78: 810-815. 
Covani, U., Canullo, L., Toti, P., Alfonsi, F. \& Barone, A. (2014) Tissue stability of implants placed in fresh extraction sockets. A 5-year single-cohort prospective study. Journal of Periodontology 85: 323-332.

De Rouck, T., Collys, K., Wyn, I. \& Cosyn, J. (2009) Instant provisionalization of immediate single-tooth implants is essential to optimize esthetic treatment outcome. Clinical Oral Implants Research 20: 560-570.

Den Hartlog, L., Huddleston, J.J.R., Vissink, A., Meijer, H.J.A \& Raghoebar, G.M. (2008) Treatment outcome of immediate, early and conventional single-tooth implants in the aesthetic zone: a systematic review to survival, bone level, soft-tissue, aesthetics and patient satisfaction. Journal of Clinical Periodontology 35: 1073-1086.

Degidi, M., Daprile, G., Nardi, D. \& Piatelli, A. (2012) Buccal bone plate in immediately placed and restored implants with Bio-Oss ${ }^{\circledR}$ collagen graft: a 1-year follow-up study. Clinical Oral Implants Research 24: 1201-1205.

Discepoli, N., Vignoletti, F., Laino, L., de Sanctis, M., Muñoz, F. \& Sanz, M. (2014) Fresh extraction socket: spontaneous healing vs. immediate implant placement. Clinical Oral Implants Research 00: 1-6.

Donnenfeld, O.W., Marks, R. \& Glickman, I. (1964) The apically repositioned flap - a clinical study. Journal of Periodontology 35: 381- 387. 
Esposito, M., Grusovin, M.G., Polyzos, I.P., Felice, P. \& Worthingtion, H.V. (2010) Interventions for replacing missing teeth: dental implants in fresh extraction sockets (immediate, immediate-delayed and delayed implants). Cochrane Database of Systemic Reviews: CD005968.

Evans, C.D.J. \& Chen, S.T. Esthetic outcomes of immediate implant placements (2008) Clinical Oral Implants Research 19: 73-80.

Ferrus, J., Cecchinato, D., Pjetursson, E.B., Lang, N.P., Sanz, M. \& Lindhe, J. (2010) Factors influencing ridge alterations following immediate implant placement into extraction sockets. Clinical Oral Implants Research 21: 22-29.

Fickl, S., Kebschull, M., Schupbach, P., Zuhr, O., Schlagenhauf, U. \& Hürzeler, M.B. (2011) Bone loss after full-thickness and partial-thickness flap elevation. Journal of Clinical Periodontology 38: 157-162.

Gher, M.E., Quintero, G., Assad, D., Monaco, E. \& Richardson, A.C. Bone grafting and guided bone regeneration for immediate dental implants in humans. Journal of Periodontology 65: 881891.

Grunder, U., Gracis, S. \& Capelli, M. (2005) Influence of the 3-D bone-to-implant relationship on esthetics. The International Journal of Periodontics \& Restorative Dentistry 25: 113-119

Hämmerle, C.H.F., Chen, S.T. \& Wilson, T.G., Jr. (2004) Consensus statements and recommended clinical procedures regarding the placement of implants in extraction sockets. The International Journal of Oral Maxillofacial \& Implants 19 (Suppl.): 26-28. 
Hämmerle, C.H.F., Araujo, M.G. \& Simion, M. On behalf of the Osteology Consensus Group 2011. (2012) Evidence-based knowledge on the biology and treatment of extraction sockets. Clinical Oral Implants Research 23 (Suppl. 5): 80-82.

Hof, M., Pommer, B., Ambros, H., Jesch, P., Vogl, S. \& Zechner, W. (2015) Does timing of implant placement affect implant therapy outcome in the aesthetic zone? A clinical, radiological, aesthetic and patient-based evaluation. Clinical Implant Dentistry and Related Research 17: 1188-1199.

Huynh-Ba, G., Pjetursson, B.E., Sanz, M., Cecchinato, D., Ferrus, J., Lindhe, J. \& Lang N.P. (2010) Analysis of the socket bone wall dimensions in the upper maxilla in relation to immediate implant placement. Clinical Oral Implants Research 21: 37-42.

Iasella, J.M., Greenwell, H., Miller, R.L., Hill, M., Drisko, C., Bohra, A.A. \& Sheetz, J.P. (2003) Ridge preservation with freeze-dried bone allograft and a collagen membrane compared to extraction alone for implant site development: a clinical and histologic study in humans. Journal of Periodontology 74: 990-999.

Januário, A.L., Rodrigues Duarte, W.A., Barriviera, M., Mesti, J.C., Araújo, M.G. \& Lindhe J. (2011) Dimension of the facial bone wall in the anterior maxilla: a cone-beam computed tomography study. Clinical Oral Implants Research 22:1168-1171.

Jung, R.E., Zembic A., Pjetursson, B.E., Zwahlen, M. \& Thoma, D.S. (2012). Systematic review of the survival rate and the incidence of biological, technical, and aesthetic complications of 
single crowns on implants reported in longitudinal studies with a mean follow-up of 5 years. Clinical Oral Implants Research 23: 2-21.

Jung, R.E., Phillipp, A., Annen, B.M., Signorelli, L., Thoma, D.S., Hämmerle, C.H.F, Attin, T. \& Schmidlin, P. (2013) Radiographic evaluation of different techniques for ridge preservation after tooth extraction: a randomized controlled clinical trial. Journal of Clinical Periodontology 40:90-98.

Jung, R.E., Zaugg, B., Phillip, A.O.H., Truninger, T.C., Siegenthaler, D.W. \& Hämmerle, C.H.F. (2013) A prospective, controlled clinical trial evaluating the clinical, radiological and aesthetic outcome after 5 years of immediately placed implants in sockets exhibiting periapical pathology. Clinical Oral Implants Research 24 839-846.

Kan, J.Y., Rungcharassaeng, K., Umezu, K. \& Kois, J.C. (2003). Dimensions of peri-implant mucosa: an evaluation of maxillary anterior single implants in humans. Journal of Periodontology 74: 557-562.

Koh, R.U., Tae-Ju, O., Rudek, I., Neiva, G.F., Misch, C.E., Rothman, E.D. \& Wang, H.L. (2011) Hard and soft tissue changes after crestal and subcrestal immediate implant placement. Journal of Periodontology 82: 1112-1120.

Lang, N.P., Tonetti, M.S., Suvan, J.E., Bernard, J.P., Boticelli, D., Fourmousis, I., Hallund, M., Jung, R., Laurell, L., Salvi, G., Shafer, D. \& Weber, H-P. (2007) Immediate implant placement with transmucosal healing in areas of aesthetic priority: a multicentre randmozed-controlled clinical trial I. Surgical outcomes. Clinical Oral Implants Research 18: 188-196. 
Lang, N.P., Pun, L., Lau, K.Y., Li, K.Y. \& Wong, M.C.M. (2012) A systematic review on survival and success rates of implants placed immediately into fresh extraction sockets after at least 1 year. Clinical Oral Implants Research 23 (Suppl.): 39-66.

Lazzara, R.J. (1989) Immediate implant placement into extraction sites: surgical and restorative advantages. The International Journal of Periodontics \& Restorative Dentistry 9:332-43.

Lee, C.T., Chiu, T.S., Tarnow, D. \& Stoupel, J. (2014) Alterations of the bone dimension following immediate implant placement into extraction socket: systematic review and metaanalysis. Journal of Clinical Periodontology 41: 914-926.

Lee, A.E., González-Martín, O. \& Fiorellini, J. (2014) Lingualized flapless implant placement into fresh extraction sockets preserves buccal alveolar bone: a cone beam computed tomography study The International Journal of Periodontics \& Restorative Dentistry 34: 61-68.

Lindebom, J., Tjiook, Y. \& Kroon, F. Immediate placement of implants in periapical infected sites: a prospective randomized study in 50 patients. (2006) Oral Surgery, Oral Medicine, Oral Pathology, Oral Radiology and Endodontics 101: 705-710.

Miglioratti, M., Amorfini, L., Signori, A., Silvestrini-Biavati, A. \& Benedicenti, S. (2013) Clinical and aesthetic outcome with post-extractive implants with or without soft tissue augmentation: a 2-year randomized clinical trial. Clinical Implant Dentistry and Related Research doi: 10.1111/cid.12194 
Montenegro, R., Needleman, I., Moles, D. \& Tonetti, M. (2002) Quality of RCTs in periodontology - a systematic review. Journal of Dental Research 81: 866-870.

Morimoto, T., Tsukiyama, Y., Morimoto, K. \& Koyano, K. (2014) Facial bone alterations on maxillary anterior single implants for immediate placement and provisionalization following tooth extraction: a superimposed cone beam computed tomography study. Clinical Oral Implants Research 00: 1-7.

Nieri, M., Clauser, C., Franceschi, D., Pagliaro, U., Saletta, D. \& Pini-Prato, G. (2007) Randomized clinical trials in implant therapy: relationships among methodological, statistical, clinical, paratextual features and number of citations. Clinical Oral Implants Research 18: 419431.

Paolantonio, M., Dolci, M., Scarano, A., d'Archivio, D., Placido, G., Tumini, V. \& Piatelli, A. (2001) Immediate implantation in fresh extraction sockets. A controlled clinical and histological study in man. Journal of Periodontology 72: 1560-1571.

Pieri, F., Aldini, N.N., Marchetti, C. \& Corinaldesi, G. (2011) Influence of implant-abutment interface design on bone and soft tissue levels around immediately placed and restores singletooth implants: a randomized controlled clinical trial. The International Journal of Oral Maxillofacial \& Implants 26: 169-178.

Raes, F., Cosyn, J., Crommelinck, E., Coessens, P. \& De Bruyn, H. (2011) Immediate and conventional single implant treatment in the anterior maxilla: 1-year results of a case series on hard and soft tissue response and aesthetics. Journal of Clinical Periodontology 38: 385-394. 
Ramaglia, L., Sbordone, C., Saviano, R., Martuscelli, R. \& Sbordone, L (2015) Marginal masticatory mucosa dimensional changes in immediate post-extractive implants: a 2-year prospective cohort study. Clinical Oral Implants Research 26: 1495-1502.

Razavi, T., Palmer, R.M., Davies, J., Wilson, R. \& Palmer, P.J. (2010) Accuracy of measuring the cortical bone thickness adjacent to dental implants using cone beam computed tomography. Clinical Oral Implants Research 21: 718-725.

Roe, P., Kan, J.Y.K., Rungcharassaeng, K., Caruso, J.M., Zimmerman, G. \& Mesquida, J. (2012) Peri-implant facial bone following immediate placement and provisionalization of maxillary anterior single implants: a 1-year cone beam computed tomography study. The International Journal of Oral Maxillofacial \& Implants 27: 393-400.

Sanz, M.,Cechinato, D., Ferrus, J., Pjetursson, E.B., Lang, N.P., \& Lindhe, J. (2010) A prospective, randomized-controlled clinical trial to evaluate bone preservation using implants with different geometry placed into extraction sockets in the maxilla. Clinical Oral Implants Research 21: 13-21.

Sanz, I., García-Gargallo, M., Herrera, D., Martin, C., Figuero, E. \& Sanz, M. (2011) Surgical protocols for early implant placement in post-extraction sockets. A systematic review. Clinical Oral Implants Research 00: 1-13.

Slagter, K.W., den Hartog, L., Bakker, N.A., Vissink, A., Meijer, H.J. \& Raghoebar, G.M. (2014) Immediate implant placement of dental implants in the esthetic zone: a systematic review and pooled analysis. Journal of Periodontology 85: 241-250. 
Schulte, W. \& Heimke, G. (1976) The Tübinger immediate implant. Quintessenz 27: 17-23.

Schultze, R.K.W., Berndt, D. \& d'Hoedt, B. (2010) On cone-beam computed tomography artifacts induced by titanium implants. Clinical Oral Implants Research 21: 100-107.

Shiratori, L.N., Marotti, J., Yamanouchi, J., Chilvarquer, I., Contin, I. \& Tortamano-Neto, P. Measurement of buccal bone volume of dental implants by means of cone-beam computed tomography. Clinical Oral Implants Research 23: 797-804.

Takeshita, W.M., Vessoni-Iwaki, L.C.V., Chicarelli-Da Silva, M.C. \& Hernandes-Tonin. (2014) Evaluation of diagnostic accuracy of conventional and digital periapical radiography, panoramic radiography and cone beam computer tomographu in the assessment of alveolar bone loss. Contemporary Clinical Dentistry 5: 318-323.

Tan, W.L., Wong, T.L.T., Wong, M.C.M. \& Lang, N.P. (2012) A systematic review of postextractional alveolar hard and soft tissue dimensional changes in humans. Clinical Oral Implants Research 23 (Suppl. 5): 1-21.

Tarnow, D.P., Chu, S.J., Salama, M.A., Stappert, C.F.J., Salama, H., Garber, D.A., Sarnachiarro, G.O., Sarnachiarro, E., Gotta, S.L. \& Saito, H. (2014) Flapless postextraction socket implant placement in the esthetic zone: part 1. The effect of bone grafting and/or provisional restoration on facial-palatal ridge dimensional change - a retrospective cohort study. The International Journal of Periodontics \& Restorative Dentistry 34: 323-331. 
Teughels, W., Merheb, J. \& Quirynen, M. (2009) Critical horizontal dimensions of interproximal and buccal bone around implants for optimal aesthetic outocmes: a systematic review. Clinical Oral Implants Research 20 (Suppl.4): 134-145.

Tomasi C., Sanz M., Cecchinato D., Pjetursson B., Ferrus J., Lang, N.P. \& Lindhe J. (2010). Bone dimensional variations at implants placed in fresh extraction sockets: a multilevel multivariate analysis. Clinical Oral Implants Research 21: 30-36.

Valentini, P., Abensur, D., Albertini, J.F. \& Rocchesani, M. (2010) Immediate provisionalization of single extraction-site implants in the esthetic zone: a clinical evaluation. The International Journal of Periodontics \& Restorative Dentistry 30: 40-51.

Van der Weijden, F., Dell'Acqua, F. \& Slot, D.E. (2009) Alveolar bone dimensional changes of post-extraction sockets in humans: a systematic review. Journal of Clinical Periodontology 36: 1048-1058.

Vignoletti, F., Matesanz, P., Rodrigo, D., Figuero, E., Martín, C. \& Sanz, M. (2012) Surgical protocols for ridge preservation after tooth extraction. A systematic review. Journal of Clinical Periodontology 39: 91-97.

Vignoletti, F., Discepoli, N., Müller, A., de Sanctis, M., Muñoz, F. \& Sanz, M. (2012) Bone modelling at fresh extraction sockets: immediate implant placement versus spontaneous healing. An experimental study in the beagle dog. Clinical Oral Implants Research 23 (Suppl.5): 22-38. 
Vignoletti, F. \& Sanz, M. (2014) Immediate implants at fresh extraction sockets: from myth to reality. Periodontology 2000 66: 132-152.

Watzek, G., Haider, R., Mensdorff-Poully, N. \& Haas, R. (1995) Immediate and delayed implantation for complete restoration of the jaw following extraction of all residual teeth: a retrospective study comparing different types of serial immediate implantation. The International Journal of Oral \& Maxillofacial Implants 10:561-567.

Werbitt, M.J. \& Goldberg, P.V. (1992) The immediate implant: bone preservation and bone regeneration. The International Journal of Periodontics \& Restorative Dentistry 12: 206-17.

Wöhrle, P.S. (1998). Single-tooth replacement in the aesthetic zone with immediate provisionalization: fourteeh consecutive case reports. Practical Periodontics and Aesthetic Dentistry 10: 1107-1114. 
ANNEXES 


\section{ANNEX I: Approval of the PhD project}

Universitat

Internacional

de Catalunya

Sr/a. Fabio Mazzocco

Benvolgut/da Sr/a.

Per la present, li comunico que la Comissió Acadèmica del Doctorat en odontologia, en la seva sessió del 26 d' octubre del 2012, i un cop estudiada la seva sol-licitud ha acordat:

S'acorda admetre al Sr. Fabio Mazzocco al Període de Recerca del Doctorat en Odontologia.

S'acorda aprovar el Projecte de Tesi titulat "Radiographic measurements of the tridimensional variation of the bone volume after immediate implant placement and insertion of an anorganic bovine bone in the space between the implant and the extraction socket ." i nomenar al Professor Edoardo Stellini i el Dr. José Nart com a Directors de la Tesi.

Addicionalment, s'informa que la normativa de la UIC estableix que cal obtenir una avaluació favorable del Comitè d'Ėtica en la Recerca, abans de la posada en marxa de la investigació. Haurà d'aportar aquest informe quan l'obtingui.

Aprofito l'avinentesa per saludar-la cordialment,

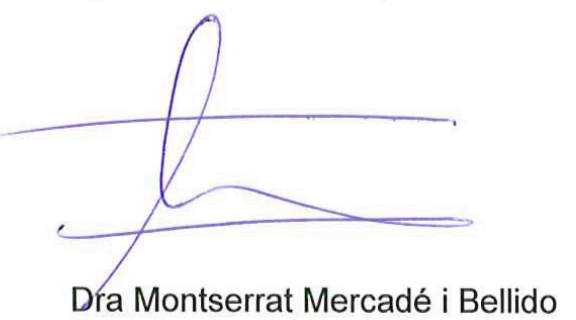

Universitat Internacional

de Catalunya

Facultat d'Odontologia

Coordinadora Comissió Acadèmica de Doctorat en Odontologia

Facultat d'Odontologia

Sant Cugat del Vallès, 26 d' octubre del 2012 


\section{ANNEX II: Approval of the Etic Committee}

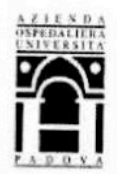

REGIONE VENETO

AZIENDA OSPEDALIERA E UNIVERSITA' DEGLI STUDI DI PADOVA

COMITATO ETICO PER LA SPERIMENTAZIONE

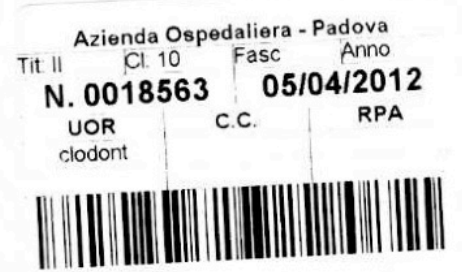

Chiarissimo

Prof. Edoardo Stellin

Clinica Odontoiatrica

Sede

Oggetto: comunicazione parere sullo studio clinico: "Research Project. Radiographic measurements of the tridimensional variation of the bone volume after immediate implant placement and insertion of an anorganic bovine bone in the space between the implant and the extraction socket". (Prot.n. 2571P).

Con la presente si invia, in allegato, il parere che il Comitato Etico per la Sperimentazione ha espresso nella seduta del 12 Marzo 2012 sullo studio clinico in oggetto.

Segreteria Scientifica

del Comitato etico per la Sperimentazione

(Dott.ssa Lodovica Gambato)

Colonice gain bofo 


\section{Nota informativa per il paziente e modulo di consenso informato}

Titolo dello studio: Radiographic measurements of the tridimensional variation of the bone volume after immediate implant placement and insertion of an anorganic bovine bone in the in the space between the implant and the extraction socket.

Codice studio:

Centro $\mathbf{N}^{\circ}$ :
Iniziali del paziente:...........

ID del paziente:

Le viene proposto di prendere parte ad un protocollo di ricerca. Prima di decidere se vuole partecipare è importante che Lei capisca gli scopi della ricerca, le relative implicazioni, i possibili rischi e benefici e le modalità di utilizzo dei dati da Lei ricavati. La preghiamo pertanto di leggere attentamente le informazioni seguenti. Se Lei sta partecipando ad un altro studio, non può partecipare a questa ricerca.

\section{QUAL E' IL MOTIVO E LO SCOPO DELLO STUDIO?}

Scopo dello studio è misurare la contrazione nel tempo degli innesti di osso che vengono routinariamente eseguiti contemporaneamente all'estrazione del dente ed all'inserimento dell'impianto dentale, utilizzato per sostituire i denti estratti. Viene inoltre valutato il ruolo del sollevamento della gengiva eseguito a volte per consentire l'estrazione di frammenti radicolari non estraibili senza scollare la gengiva. Nonostante tale tecnica sia ampiamente utilizzata e ben descritta in letteratura, riportando successi implantari del $95 \%$, non esistono studi che valutino l'entità della contrazione dell'innesto d'osso nei 6 mesi successivi all'inserimento implantare. Lo studio quindi non riguarderà la procedura ma semplicemente le misurazioni eseguite sulle radiografie prime e dopo l'intervento chirurgico.

\section{MODALITA' DI PARTECIPAZIONE ALLO STUDIO}

Dipende da Lei decidere di partecipare o no. Se decide di partecipare Le viene chiesto di firmare questo modulo di Consenso Informato, fermo restando che la Sua partecipazione non influenzerà il livello di cure che riceverà.

Le cure che riceverà non saranno influenzate dalla partecipazione allo studio.

II trattamento che riceverà sarà infatti routinario ed eseguito presso lo studio privato del Dr Mazzocco. Se decide di partecipare allo studio ci consente ad analizzare e confrontare le radiografie eseguite prima e dopo il trattamento chirurgico presso L’Università degli Studi di Padova. 
Firmando questo modulo, lei autorizza il Medico ed il suo staff a raccogliere e ad elaborare i Suoi dati personali, tra cui:

- La Sua data di nascita

- Il sesso

- La Sua origine etnica

- I suoi dati clinici tra cui le radiografie eseguite prima e dopo l'intervento

- Qualunque altro elemento personale ottenuto nel corso della Sua partecipazione allo studio o come risultato di una qualunque visita di controllo

Qualora Lei ritiri il Suo consenso all'utilizzazione dei Suoi dati, cesserà automaticamente la Sua partecipazione allo studio.

Tenga inoltre presente che i risultati dello studio potranno essere pubblicati su riviste mediche, ma la Sua identità non sarà rivelata.

\section{ULTERIORI INFORMAZIONI}

Qualora Lei voglia porre ulteriori domande relative allo studio in oggetto, La preghiamo di contattare:

Dott.

Infermiera

Num di tel:

Indirizzo:

\section{CONSENSO INFORMATO ED AUTORIZZAZIONE}

Ho ricevuto informazioni verbali sullo studio in questione ed ho letto la nota informativa allegata.

Mi è stata data la possibilità di discutere lo studio e fare domande.

Acconsento a partecipare allo studio e sono consapevole che la partecipazione è completamente volontaria.

So che posso ritirarmi in qualsiasi momento senza che ciò comprometta le mie cure future.

Firmando questa nota informativa e questo consenso informato, consento che i miei dati personali, inclusi i dati relativi alla mia salute sia fisica che mentale, alla mia origine etnica, possano essere utilizzati conformemente a quanto previsto nel consenso informato. 
Nome del paziente (scrivere in stampatello maiuscolo)

Firma di chi ha condotto la discussione

data della firma

sul consenso informato

Nome della persona che ha condotto la discussione

sul consenso informato (scrivere in stampatello maiuscolo) 